$1-1-1938$

\title{
Epistle to the farm : the report of the director, West Virginia Agricultural Experiment Station, Morgantown, for the biennium 1936 to 1938
}

C. R. Orton

Follow this and additional works at: https://researchrepository.wvu.edu/ wv_agricultural_and_forestry_experiment_station_bulletins

\section{Digital Commons Citation}

Orton, C. R., "Epistle to the farm : the report of the director, West Virginia Agricultural Experiment Station, Morgantown, for the biennium 1936 to 1938" (1938). West Virginia Agricultural and Forestry Experiment Station Bulletins. 290.

https://researchrepository.wvu.edu/wv_agricultural_and_forestry_experiment_station_bulletins/291 @ WVU. It has been accepted for inclusion in West Virginia Agricultural and Forestry Experiment Station Bulletins by an authorized administrator of The Research Repository @ WVU. For more information, please contact ian.harmon@mail.wvu.edu. 


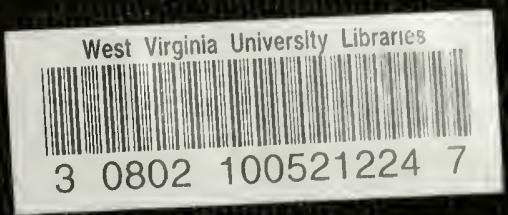





\section{Epistle to the Farm}

BY C. R. ORTON

The Report of the Director, West Virginia Agricultural Experiment Station, Morgantown, For the Biennium 1936 to 1938 (Bulletin 290 December, 1938) 


\section{THE AGRICULTURAL EXPERIMENT STATION}

\section{of \\ WEST VIRGINIA UNIVERSITY \\ Morgantown}

December 15, 1938

\section{TO THE MAN ON THE LAND :}

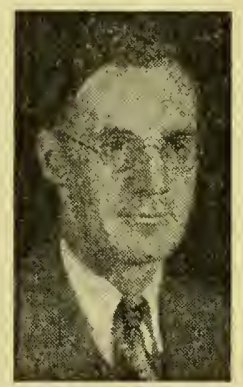

I wish I could drop in on you some evening, light my pipe, and chat with you about your farm and home problems as well as the problems of your community, and your State, and what the different agencies of the State and Nation are trying to do to help you with your particular problems. Since that is impossible $I$ am sending you this message.

Maybe you wonder why this letter is written to the farm instead of to you personally. Well, to me, the farmer and his farm are one. That is true wherever you go. The land, you know, is basic - so fundamental that a great national organization - the Institute for Research in Land Economics and Public Utilities - has captured the significance of this fact in a motto - "UNDER ALL, THE LAND."

In the pages that follow you uill find some of the things that the Agricultural Experiment Station of West Virginia University is doing on your behalf. The research breaks up into farm crops and soils, animal husbandry, dairy husbandry, chemistry, fruit and vegetable crops, plant disease and insect control, farm economics, forestry, and nutrition. All these are included in this report, written in non-technical language. And somewhere you will see the tie-up with your own farm enterprise.

Believe me, yours,

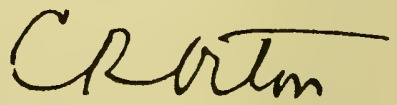

P.S. Don't think that you have to read this bulletin all in one sitting. Keep it on the mantle, or behind the clock, and pick it up now and then to read a chapter. It may be two years before I get around to another letter, and this one will have to do until then. In the mean time, if you would like to have your name on our mailing list to get our farm bulletins, let me know.

C. R. O. 
Finishing calves on little grain and much pasture . . . 4

Results of Corriedale x Hampshire backcross . . . . 5

Drug poisons for sheep parasites . . . . . . . . . 6

How and what shall we feed chickens? . . . . . . 8

Sudan is a lifesaver for cows in midsummer . . . . . 10

Should we simplify our dairy rations? . . . . . . . 11

Lack of vitamin may cause off flavors in milk . . . . 13

A hybrid corn for every region? . . . . . . . . . 16

A sweet clover free of coumarin? . . . . . . . . . 17

Our soils are low in phosphorus . . . . . . . . . 17

Alfalfa needs lime and then fertilizer . . . . . . 18

Apple roots go deep in limestone soils . . . . . . 20

There is profit in blueberries . . . . . . . . . 22

Green manures for cabbage and tomato . . . . . . 23

Use complete fertilizer for potato . . . . . . . . . 24

What is the West Virginia Forest Products Association? 26

Can we influence color in the apple? . . . . . . . . 29

Black-walnut meats can be kept fresh . . . . . . . 30

Black rootrot is highly contagious . . . . . . . 32

When are sprays injurious to fruit? . . . . . . . . 33

The plight of the chestnut tree . . . . . . . . . 34

What progress in arsenic substitutes? . . . . . . . 35

The timing of sprays and the weather factor . . . . 37

Vitamins in growth and health . . . . . . . . . . 40

What is a fair basis for real-estate tax assessments? . . 42

Upshur county, U. S. A. . . . . . . . . . . . . 42

How much food do we grow at home? . . . . . . . 45

Publications of the biennium 1936-1938 . . . . . . 50 


\section{ANIMAL HUSBANDRY}

CATTLE AND SHEEP have been and are the mainstay of West . Virginia's agriculture, and nearly every farm in the State has more or less poultry. Problems continue to arise in connection with the breeding, feeding, and marketing of these animals - problems that require an answer.

\section{Ensilage Corn for Steers?}

Which would you rather feed your yearling steers - Cocke's Prolific, or Boone County White corn? For an answer to this question our animal husbandmen - E. A. Livesay, M. L. Buchanan, and A. H. VanLandingham - went to the feedlot and let the steers do the talking.

Boone, you know, is a heavy tonnage field variety of white corn, while the other is an ensilage variety. For three years we compared these two in three ways: (1) yields of green tonnage and of dry matter per acre; (2) chemical analysis of dry matter; and (3) the value of dry matter when fed to cattle in the winter.

Taking it from year to year, we found that the green tonnage varied somewhat; but on the basis of acre yield of dry matter, there was little difference, on the average, between the two varieties. The Cocke's Prolific had more moisture. Perhaps that is why winter rations composed of the same weight of silage always favored the Boone County White. But when we put it on the dry-matter basis, pound for pound, we found no important difference between the two varieties in the gains made by the steers. This experiment was carried on at Morgantown.

\section{Finishing Calves on Little Grain and Much Pasture}

In West Virginia, as in any state where the snow flies, there are just two seasons - the pasture and the drylot season. How can we manage beeves for the best utilization of feed?

A herd of 70 high-grade Hereford cows bred to purebred registered bulls is maintained at Lewisburg for the production of beef calves. These calves are dropped in the spring around April 1, run with their dams until November 1, weaned, and started on feed. At the end of 28 days after weaning, or around December 1, the calves are placed in winter quarters and fed a ration of corn silage, clover hay, cottonseed meal, and coarsely-ground corn until May 1. The daily amount of grain in the winter ration has been a little under four 
pounds, never above. C. V. Wilson has this project in charge and the next project (on sheep breeding) too.

Heifers and steers get the same ration but are kept separate. From eight to ten of the top heifers are kept for herd replacement, and old or otherwise unsatisfactory cows are sold.

On or about May 1 the calves are turned to pasture and fed a limited amount of corn. For the first 56 days this amount has not exceeded four pounds per head daily. Through the third period of 28 days the grain fed has been doubled, and during the fourth period, up until marketing around August 1 to 15, when pastures get dry, the grain is increased to a full feed.

The results of two trials - 1936-37 and 1937-38 - indicate that (1) very satisfactory weights of from 800 to 875 pounds may be obtained; (2) the maximum of grass and home-grown roughages may be marketed satisfactorily and profitably; (3) excellent values of $\$ 40$ to $\$ 50$ are realized for both steer and heifer calves at weaning time; and (4) in 16 months approximately 1000 pounds of grain, plus good roughage and pasture, serves to make desirable carcasses, grading good to choice, out of calves so grown and fed. In an area of limited tillable land and extensive pasture lands, this plan has merit.

\section{Effects of Back-crossing Corriedale $\times$ Hampshire on Wool and Mutton}

For several years now, the Experiment Station has been studying the results of crosses between Hampshires and Corriedales to see what could be done in the direction of heavier native fleeces and tastier carcasses.

One hundred twenty native grade Hampshire type ewes were selected in 1929 from a flock with a known history. These ewes were bred in the fall of 1930 in lots of 30 head to four Corriedale rams, one ram to each lot. The ewe lambs from this mating were all retained for breeding (back) to Corriedale rams. The wether lambs were slaughtered at Beltsville, Maryland, for the purpose of meat investigations by the Bureau of Animal Industry of the U. S. Department of Agriculture.

The ewe progeny has been bred until the third generation of Corriedale-sired ewes has been produced.

In weight, in gains, in carcass grades, and in dressed yields, the wether lambs of the first cross were found to be the equal of wether lambs sired by Hampshire or Shropshire rams and out of similar ewes. The first-cross ewes proved excellent mothers; they yielded a fleece staple approximately one inch longer than their dams' fleece. 
Besides, it was of equal fineness and density, and over 50 percent heavier in grease weight.

In the progeny of the second or back-cross ewes we found considerable improvement in the length, weight, and fineness of fleece over the original grade Hampshire-type ewes, but they were slightly inferior to their dams in size of ewe and in weight of fleece, both grease and clean.

The second-cross wether lambs have not proved the equal of the first-cross lambs in average daily gains, in final weight, in finish, and in yield at slaughter, or in the live or carcass grade. They averaged seven pounds lighter in weight at the same age and one-third of a grade lower in the carcass than wether lambs of the first cross.

Definite results on the third-cross lambs cannot be reported at this time, but the same general trend of inequality seems to show up. The second-cross lambs are somewhat superior to the third cross, just as the first cross was ahead of the second cross (in the points mentioned). The work is being continued until enough information is at hand to report definite results on the third-cross wethers and on the third-cross ewes and their progeny.

\section{Drug Poisons for Sheep Parasites}

What sheep producer has not been troubled with stomachworms and other ailments in his flock? Parasites are one of the important problems facing the industry in this state.

In 1929 our animal disease specialist, J. H. Rietz, began a study of several drugs used in removal or control of intestinal parasites. Best results have come from drenching with a $11 / 2 \%$ solution of copper sulphate. When administered every 21 days, this remedy was effective in controlling stomachworms, tapeworms, and nodularworms, but not cooperia (a small stomachworm). It takes equal parts of a $1 \frac{1}{2} \%$ solution of copper sulphate and of nicotine sulphate to control this parasite.

In recent years the experiment has taken a different turn, to see when systematic treatment should begin for stomach and intestinal worms. Some lots of lambs were begun at seven weeks of age. Other lots were left untreated until weaning time or until they were $4 \frac{1}{2}$ to 5 months old. All lambs were fed through the drylot period so as to be finished for market. In the first year's trial, 15 were treated and 15 were left untreated. The grade of lamb and their market weights showed no particular differences between the two groups in this set, but the lambs treated with copper sulphate showed a cold carcass yield $2 \%$ higher than that of the untreated lambs. 


\section{The Animal Disease Laboratory}

Our animal disease laboratory, besides carrying on the research just mentioned, performs a great deal of diagnostic work, to help the general public in the prevention and control of disease. The record for the past two years shows that examinations were made on 11,846 animals, or on specimens of material from such animals. These included cattle, horses, sheep, swine, mules, dogs, cats, rabbits, chickens, turkeys, ducks, and man. Some 9000 of these examinations were made in connection with the official work of the Experiment Station as well as other units of West Virginia University.

The examinations consisted of 4064 specimens of blood from cattle, chickens, turkeys, dogs, and man; 4600 samples of milk from cows; 826 samples of feces for the determination of parasite infestation in cattle, horses, sheep, swine, dogs, chickens, and man; 1248 autopsies on cattle, swine, sheep, dogs, cats, chickens, turkeys, ducks, and rabbits; 36 organs or parts of organs from cattle, sheep, swine, dogs, chickens, goats, and rabbits; 3 specimens of vaginal discharge from cows; 2 specimens of skin scrapings from cattle; 5 samples of urine from horses and man; 49 brains for rabies from cattle, sheep, swine, dogs, and cats; 11 specimens of semen from cattle and horses; and 2 identifications of parasites from sheep and man.

\section{Protein Source Determines Poultry Ration's Efficiency}

Soybean oilmeal, when it is the only source of protein in a laboratory diet for chickens, makes for better growth than either meat scraps or fish meal. There is a wide variation in the efficiency of the protein supplements being used in poultry rations, and the fact that many mash mixtures on the market are low in efficiency, prompted $\mathrm{T}$. B. Clark and A. H. VanLandingham to make a thorough study of the problem.

Proteins from animal and plant sources are studied alone and in various combinations. The feeds are added to a semi-purified basal diet low in nitrogen, then are studied by two methods - growth trials and balance trials.

Results so far show that the efficiency of meat scraps is increased considerably when fish meal is added. But meat scraps plus soybean oilmeal gives better growth than fish meal plus oilmeal.

\section{Mortality and Protein Level are not Related}

Is there a poultryman in West Virginia who is not disturbed by high mortality in his flock? It is one of the major problems confronting the industry in this State. 
In 1936 T. B. Clark, J. H. Rietz, and C. E. Weakley, Jr., began to look into the matter. These experimenters felt that there might be some connection between mortality and White Leghorn rations that were high $(181 / 2 \%)$ or low $(131 / 2 \%)$ in protein. During the laying periods of these two years the deaths have been just about equal in all the lots. In other words, the difference in protein content of the mashes had no effect on mortality. Something else is responsible. Incidentally, half of the deaths were due to diseases like leukemia and leucosis (diseases of the liver or bloodstream).

\section{The Right Battery Ration Prevents Slipped Tendons}

Battery brooders and mother hens are not the same thing when it comes to producing a normal, healthy chick. The brooder chick, when it is about six weeks old, develops a leg deformity called perosis, or slipped tendons. This cuts down his market value when he is offered as a broiler.

Other experiment stations have found that manganese in the ration prevents the occurrence of the deformity. But how much? Standard middlings and wheat bran are high in this mineral, but ' $\Gamma$. B. Clark and A. H. VanLandingham found that it takes as much as $30 \%$ of either of these feeds to prevent perosis and assure normal growth.

\section{How and What Shall We Feed Chickens?}

Poultry is equipped with a digestive system unlike that of all other classes of live stock. Grains are swallowed, not chewed. And that brings up the subject of testing various rations as well as methods of feeding grain.

E. T. Wightman says he gets satisfactory egg production when pullets have free access to whole grains and to mash, both fed from hoppers. He finds that the pullets (S. C. White Leghorns) are able to adjust their intake of protein by consuming more or less grain, depending on the protein content of the mash. In all cases, when he fed the pullets concentrated mashes, the percentage of whole grain to total feed has increased, while the total feed consumed has remained about the same. We believe that poultrymen with home-grown grains might well utilize these grains to advantage, and supplement these by buying smaller quantities of more concentrated mashes.

Here are some other results of our experiment:

Different combinations of ground oats, wheat middlings, and bran, added to the same formula of concentrate, all gave satisfactory results. 
Thirty-five pounds of wheat middlings substituted for 25 pounds of whole ground wheat gave practically the same production and the same feed requirement for each dozen of eggs.

Thirty pounds of whole ground wheat gave better production and fewer deaths than a similar mash with 20 pounds of middlings and 10 pounds of bran.

Wheat middlings compared with the same amount of ground oats in a mash concentrate favored the middlings because of fewer deaths and better production.

In two lots of pullets fed alfalfa leaf meal at levels of $5 \%$ and $10 \%$, those receiving the $10 \%$ alfalfa showed greater mortality, gave lower production, and required more feed per dozen of eggs.

In this experiment, the feed has ranged from 4.63 to 5.78 pounds for each dozen of eggs, and production over an eight-months period has ranged from $46.9 \%$ to $57.7 \%$. This production was figured on a hen-day basis, no culling being considered.

\section{Can We Change Egg Quality by Feeding?}

And what about quality? Consumer demand for eggs of high interior quality is increasing in this state. Eggs with a great deal of thick white are preferred; they are superior for storage purposes too.

Since 1936 T. B. Clark has looked into the effect of feeding six different mash mixtures on the percentage of thick white and on yolk color. He compared simple mash mixtures, as well as complex ones containing $20 \%$ protein. The grain was hopper-fed to all pullets. The percentage of thick white ranged only 4 points - from 58 to $62 \%$. This shows that rations themselves had little influence on the amount of thick white. And they had little effect on the yolk color, even when the alfalfa leaf meal was increased from 5 to $10 \%$.

\section{Improved Market Qualities in Turkeys}

Turkeys! Let's not forget them. Like the blueberries mentioned on page 22, we have a natural breeding ground in West Virginia for these birds.

Producers of market turkeys often cross two varieties to improve the market qualities. In order to test the merit of this procedure, an experiment is now under way which deals with Bronze and Bourbon Reds alone and in comparison with the crosses of the two varieties. So far the crossbred turkeys have not excelled the purebreds in either growth or market grade. Feeding efficiency in purebreds as compared with crossbreds is being studied too, for additional information on the value of crossbreeding. T. B. Clark and E. A. Livesay are looking after this study. 


\section{DAIRY HUSBANDRY}

THE DAIRY WORK at this Experiment Station is divided into 1 two branches - (1) research in breeding and milk production, and (2) research in milk and its byproducts. For a state in which dairying furnishes the largest income of any agricultural pursuit, these two types of research are essential. There is another phase, too, that must be considered in a dairy enterprise. That is the cost of production and of distribution. On page $46 \mathrm{I}$ shall tell you of our investigations in that field. Meanwhile, let's look at the pasture problem.

\section{Sudan Is a Lifesaver for Cows in Midsummer}

What should the West Virginia farmer sow to supplement his pasture in those hot, dry midsummer spells that burn up the bluegrass?

For nearly ten years we have been working with bluegrass, Sudan grass, and sweet clover at the Reymann Memorial Farm in Hardy County. There H. O. Henderson and R. A. Ackerman have found these results: bluegrass produced little more than one-third of its crop after August 1, when it is needed most; Sudan grass with soybeans, almost all; first-year sweet clover with oats, about one-half; and second-year sweet clover, almost none of its crop after that date. The average pasture days per season were: for bluegrass, 123 days; for Sudan, 89; for first-year sweet clover, 44; and for second-year sweet clover, 132 days. That last figure may seem striking, but we should not forget that the second-year sweet clover was produced almost entirely in the early part of the season, when bluegrass, too, was at its best. Sudan, on the other hand, came at a time when the bluegrass was at its poorest.

Lately we have turned to alfalfa and lespedeza to see how these will do for dairy pasture. No results yet.

\section{Dairy Heifers Benefit When Pastures Are Fertilized}

Over in the section on farm crops and plant breeding I shall point out the beneficial effects of lime and phosphorus in reestablishing pastures. Suppose we consider now how the animals grew that were supported on those greenswards.

Yearling Ayrshire heifers were pastured on the several plots, and the weight of each was taken at the times she was put on the plots and taken off again. From this information H. O. Henderson, 
R. A. Ackerman, and G. G. Pohlman calculated the amount of total digestible nutrients according to the figures given by Morrison.* Also, they kept tab on the number of pasture days furnished by an acre during the growing season.

Without mentioning figures, I can say that by adding lime and fertilizer (phosphorus, or phosphorus and potash), we got a significant increase in the number of pasture days, in the pounds of gain in animal weight per acre, and in the pounds of total digestible nutrients per acre. I repeat what I said in the agronomy section: it is doubtful that any increase from the use of nitrogen was enough to justify the cost of applying the nitrogen fertilizer.

\section{Should We Simplify Our Dairy Rations?}

Dairying is West Virginia's 15-million dollar industry. Low costs of production will give the dairyman a larger share of this income, and economical feeding methods play a very important part in reducing costs. That is why our Departments of Dairy Husbandry and Agricultural Chemistry for some years have undertaken experiments looking toward simplifying dairy rations.

G. A. Bowling and A. H. VanLandingham used simple rations composed of yellow cornmeal and alfalfa hay, both with and without pasture or corn silage, in feeding different lots of dairy cattle. Other lots got rations made up of yellow cornmeal, corn gluten meal, and timothy hay, both with and without pasture. In both cases the aim was to find out the value of such rations for growth, for reproduction, and for milk production.

Still another ration composed of yellow cornmeal, ground oats, and alfalfa hay, with pasture in season, was tried. And a fourth ration of yellow cornmeal, soybean oilmeal, timothy hay, and corn silage, again with pasture in season, was tried on still another group of milkmakers. These last two rations were fed to determine their value for milk production only.

After six years our experimenters have come to these conclusions :

1) Where growth was involved, all the rations in this project were good enough to support normal growth. Animals receiving no pasture grew just as well as those pastured in season.

2) None of these rations seemed to influence the breeding efficiency of the heifers or cows.

*Feeds and Feeding, 20th Ed. 


\section{But consider the next point:}

3) The ration composed of yellow cornmeal, corn gluten meal, and timothy hay did not seem to be an adequate one during periods of gestation. And it was not able to maintain milk production at a high level,

4) The other rations seemed to support milk production at about the same level as the production level of related herd cows that were getting a balanced herd ration. But it should be remembered that the milk-producing ability of some of the animals, as well as of their half-sisters that were used as checks, was not especially high.

In another phase of this experinent, a group of animals has been grown to production age on an alfalfa-protein ration. One animal on this ration, calving during the year, has produced over 40 pounds of milk per day when milked twice daily. Animals coming into production on the alfalfa-protein ration are not able to maintain their body weight when fed according to the Morrison feeding standard. We think that a fat deficiency in the ration may be the limiting factor. In an attempt to answer this question, 10 additional registered Holstein-Friesian calves have been started on this ration. Five of them will receive fat supplement in the form of corn oil. Five per cent of the concentrate ration is corn oil.

\section{Phosphorus Intake Is Important in Gestation}

The dairy animal is a complex organism, able to adjust itself to variations in diet and to changes in the mineral content of that diet. But for how long?

Four years ago our dairy scientists and agricultural chemists began to study the calcium and phosphorus balance in the blood of cows in gestation. H. O. Henderson and G. A. Bowling supervised the feeding, and A. H. VanLandingham made the laboratory tests to see how much inorganic phosphorus was in the blood. Nore than 200 samples of whole blood were taken from 25 Holstein-Friesian heifers, which had been divided into three groups depending on the type of ration and on management. Some of these cows were subjected to rations low in calcium and in phosphorus, and the tendencies in blood composition were noted carefully during the first, second, and third lactations. The results seem to show that, for the first lactation, the dairy heifer probably can "mobilize" enough phosphorus from the deficient diet, but for later gestation and lactation periods it is very doubtful that this can continue without serious drain on the normal composition of the cow's blood. 


\section{Are Body Type and Fat Production Related?}

Breeders of dairy cattle are striving constantly to improve the production ability of their herds. Those who are breeding registered cattle are intensely interested in the production of cattle of the most acceptable dairy type. Although the art of cattle breeding for utility purposes is as old as civilization, the science of cattle breeding is very young, and definite methods of breeding for desired characteristics are not numerous. The study in progress at the Reymann Memorial Farm was undertaken in an effort to determine the way characteristics are inherited that are important from an economic standpoint. G. A. Bowling, R. A. Ackerman, and H. O. Henderson are in charge of this project.

For the past 15 years only proved sires have been used in this experimental herd, and every normal heifer coming into milk in the herd has been tested for milk and butterfat production. A marked trend towards greater uniformity in productive ability of the cows in the herd has been noted during the past two years. Whether this trend (towards a higher and more uniform production level) can be continued remains to be seen.

This herd is maintained, as nearly as it is possible to do so, under similar environmental conditions year after year. In this way any improvements in production may be credited to a greater concentration of those genetic factors that are favorable to high production.

Animals involved in this study are photographed every year, and they are scored for body conformation at the same time that they are photographed. Notes are taken of defects and of undesirable characteristics as supplementary data for the photographic records, in order that a true picture may be kept for comparative studies after many of the animals may have died or been sold.

During the past year a few of the most promising bull calves born in the herd have been reserved for light service. After breeding about 15 females at Reymann Farm to each young bull, he will be leased to some breeder of registered Ayrshire cattle until his get in the experimental herd has been tested for production. Arrangements have been completed whereby four of these young bulls will be taken care of according to this plan. In this way proved sires of related breeding will be available in the future for line-breeding studies on a proved-sire basis.

\section{Lack of Vitamin May Cause Off Flavors in Milk}

Cappy, oily, tallowy, cardboard, papery, metallic. Who has not experienced one or more of these unpleasant tastes in milk! It all 
comes from the contact of milk with iron or copper in utensils, pipes,
or other equipment.

An intensive study of the causes of these off flavors and of methods of prevention was begun some years ago by L. M. Thurston and lately has been continued by W. C. Brown with the aid of the Department of Agricultural Chemistry. They report substantial progress. For instance, they have evidence that both vitamin $\mathrm{C}$ and carotene in the feed tend to prevent the development of this "oxidized" flavor. Just how the vitamin accomplishes this trick is not yet certain, but we do know that the carotene in the feed passes directly into the milk and so prevents this defect.

Another discovery of these scientists is that the material responsible for the off flavors is not part of the butterfat. Instead, it develops in the film around the fat globules. It has taken a deal of painstaking work to find this out.

You may have heard, now and then, that milk of high acidity always develops oxidized flavor. We have investigated this belief by studying and experimenting with 220 milk samples and we find no support for the theory.

Stranger than this is our finding that milk contaminated with copper after pasteurizing is much more susceptible to oxidized flavor than milk contaminated with copper before pasteurizing.

I repeat what was reported by this Station two years ago - milk that is pasteurized, cooled, and handled without contact with copper, before or after pasteurization, should not develop oxidized flavors.

\section{Clean Cream Is Essential for Good Butter}

Cleanliness is the first requisite in milk production, and that goes for cream too.

L. J. Manus and H. O. Henderson in the summer of 1937 made a survey of several farms on which cream is produced. Here's what they found: Under the usual farm methods of producing and holding cream, the bacterial count, after 4 days of storage at a temperature of 70 to 75 degrees F., showed hundreds of millions to the thimbleful. But when the utensils were scrubbed thoroughly with a brush, and washed with alkaline washing powder, rinsed with water immediately after each milking, and then rinsed with a chlorine solution just before use, the bacterial count was cut to less than half; that is, after four days of storage at the same temperature. And when the same cleaning methods were used and the cream cooled at once to, and stored at, 50 degrees $F$, the number of organisms was kept down to 760,000 per cubic centimeter, and the result was an excellent cream of 
high keeping quality which remained sweet to the taste for at least a week - which means that by this method it could reach the shipping station as a first-quality cream.

I think it is important for our farmers to know this, because a general improvement in the quality of our cream shipped out of state will bring about a better price to the producer of this dairy product.

\section{FIELD CROPS AND SOILS}

THE TESTING of varieties of farm crops has engaged the efforts of the Experiment Station since it was established in 1888. In recent years we have turned also to the development of strains of corn through careftul breeding programs. And we have made substantial forward strides in studying crop rotations, as well as soils and fertilizers. Let's consider the variety trials first.

\section{There are Several Superior Oat Varieties}

For three years J. A. Rigney has conducted tests in Preston county with the cooperation of a farmer at Brandonville and one at Terra Alta. On this tableland, Albion gave the highest average yield (46.1 bu.), with Gopher (42.5) and Japan Selection (44.7) just a few bushels lower. All three varieties gave better yield than the varieties commonly grown by the cooperators. Gopher is the earliest of the three, and it lodges the least on fertile bottom soils. Japan Selection ripens more than a week later. Albion is in between.

\section{We Seek a Smooth-Awned, Winter-Hardy Barley}

Rigney also tested several varieties of winter barley at Morgantown, Lakin, and Kearneysville. Kentucky No. 1 and Scottish Pearl were outstanding performers, but they have rough beards, and you know how uncomfortable those beards are. We are trying now to get a hooded strain or a smooth-awned one that is winter-hardy. To do this our plant scientists made more than 800 selections from two commercial plantings of mixed barley. So far, three or four hooded selections have shown considerable promise, but they need further testing before they can be increased and distributed with assurance.

Rod-row experiments bearing on the date of seeding have indicated that barley should be seeded two or three weeks before wheat is sown. At Morgantown, when barley was seeded by August 25, one experimental plot was clipped once with a lawn mower, without reducing the yield much. From this experience we believe that the 
farmer can get a limited amount of fall pasture if the barley seeding is done early enough.

\section{A Hybrid Corn For Every Region?}

The plant breeders - geneticists we call them - have been working on hybrid corn for West Virginia. Hybrids, you know, are crosses between established strains of a plant variety - in this case pure-breeding strains or lines of corn.

The State is quite variable in its climatic make-up, and a different hybrid will be required under each of many conditions. During the past three years we have tested numerous out-of-state commercial hybrids. So far Iowa 939 and Ohio W-17 have outyielded many of the common varieties by as much as 10 to 15 percent. But these results have been found only at elevations of 1000 to 2000 feet and only in the northern two-thirds of the State.

We are developing hybrids that may be adapted to other regions of West Virginia, but it takes at least 10 years to develop a satisfactory one of known performance, and we have not yet reached this point.

Smut resistance is another factor the geneticists are working on. In siveet corn they are developing early-maturing hybrids resistant to wilt or Stewart's disease. C. R. Burnham has been in charge of this work.

\section{Not All Rotations Contain Organic Matter}

Crop rotations have an important influence on yields. Farmers have known that for generations, but it has taken a lot of experimental work in many states to find out just how great the influence is.

At Lakin, in Mason County, G. G. Pohlman and T. C. Mcllvaine have studied many rotations over a 12-year period. Here are the results :

(1) Manure and superphosphate together have maintained yields in all rotations, but still better results were seen in rotations lasting three years or more.

(2) Generally speaking, lime has increased the yield in rotations. The effect has been most noticeable in legumes, but the yields of other crops have also benefited. This may be due to the better growth of the legumes on the limed soils.

(3) If clover was a part of a rotation of three years or more, good results came without the return of manure; but the results were better when the manure was returned.

(4) It seems that the maintenance of yields and the maintenance 
of organic matter go hand in hand. In our experience, any rotation which has kept up or increased the organic content of the soil has also given good yields. Likewise, any rotation which has maintained the yields has kept up the organic matter content.

(5) Turning the cover crops under has helped to maintain yields in a corn - soybean rotation, but this practice will not keep up high yields unless manure is also returned.

(6) In the rotations which maintain organic matter, commercial fertilizers are needed, but not in as large quantities as in rotations in which the organic matter content is not maintained. This is true especially of nitrogen fertilizers and to a lesser extent of potash.

\section{A Sweet Clover Free of Coumarin?}

We hope to develop a strain of sweet clover that is not so sensitive to soil acidity and that has a low content of coumarin - the bitter substance that cows do not like. C. R. Burnham has experimented with a number of strains for some years and so far has isolated some promising strains but these need to be tested for some seasons longer before their value can be proved. Incidentally, some strains are more resistant to frost injury than others.

\section{There Are Better Tobaccoes than Improved Kelley}

For several years T. C. McIlvaine has worked with White Burley tobacco but, as in the case of sweet clover or any crop, it takes many years to produce a plant with a known performance. He has tested this variety for both yield and quality, and several strains have shown both higher yield and better quality than the Improved Kelley variety.

\section{Our Soils Are Low In Phosphorus}

Phosphorus is one of the great needs of both the plant and the animal kingdom. I shall not enlarge on this fact except to call to your attention that the President of the United States, last May, saw fit to urge upon Congress the investigation of our national resources in this mineral, both from the standpoint of the most economical present utilization of the deposits and from the standpoint of its conservation for future generations.

There are more than 17 billion tons of phosphate rock in the world, and the United States owns three-fifths of this known supply. Some nine-tenths of our domestic supply lies in the mountain states of the Northwest. The rest lies in Florida and Tennessee. That means that one-tenth of the nation's reserve has to supply the bulk of the 
demand, which is in the East. But that's a problem for the Government to figure out. What I wanted to say was that most soils in the State of West Virginia are low in available phosphorus. That is the verdict of many tests in the greenhouse and in the field. Now G. G. Pohlman is comparing the results of these tests with various methods of determining, in advance, how much phosphorus is free or available for plant growth in any soil. He finds a fairly good relationship between the available phosphorus, determined in advance in the laboratory, and the increase in crop yield which we get by using phosphate fertilizer.

\section{Pastures Respond to Lime and Phosphate}

West Virginia pastures, if you give them a chance with lime and phosphate, can be brought back to something like their original condition of a thick stand of Kentucky bluegrass and white clover. W. H. Pierre and G. G. Pohlman are convinced of this after eight years of experimenting with more than 300 pasture plots on the chief soil types all over the State. Here are the results:

Lime and fertilizer have brought about a greater yield of herbage. And they have changed the type of vegetation from a flora made up largely of poverty grass and broomsedge, to one that showed bluegrass more than anything else.

Lime and phosphorus gave us the most marked effect. But these must be present in large enough amounts; otherwise the results will be disappointing. Nitrogen, it is true, did increase both the yield and the quality of herbage, but I doubt that the increase has been enough to warrant the cost. We have published Bulletin 289 on the subject.

At Wardensville, in Hardy County, we are comparing grazing methods and clipping with a lawn mower. So far the evidence is that the weight of clipped herbage corresponds favorably to the number of days of pasture furnished. The gain in the weight of dairy heifers has also been found related closely to the pasture days furnished.

\section{Alfalfa Needs Lime and then Fertilizer}

Alfalfa's many advantages as a fodder crop have been told for years, and they are true no less today. During the past few years, research by W. H. Pierre, G. G. Pohlman, and W. M. Broadfoot has shown that this legume can be grown successfully on most welldrained soils in the state. But it takes lime to assure a good crop. The amount needed depends on the initial acidity of the soil. If enough lime is added to bring the soil reaction to a value slightly 
above 6.00 on what we call the " $\mathrm{pH}$ " scale, there is enough to last a few years. But if the land is to be kept in alfalfa indefinitely, it will take additional applications of lime.

Superphosphate, applied at the rate of 500 pounds per acre, has given large increases in yields for four or five years, and higher rates of application have proved their worth on certain soils. The alfalfa plant uses some phosphate for its own growth. In addition, some of the phosphate applied becomes "fixed" in the soil, or unavailable to the plant. This means that, if the alfalfa stand is to be maintained for more than three years, it is desirable to make a large application the first time, and to topdress the stand at intervals of two to three years.

Another thing about phosphate. This fertilizer helps to increase the phosphorus content of the plants as well as the plant yield. The value of this can be seen when it is recalled that livestock requires a certain amount of phosphorus in the feed consumed. Our soils men found that the first cutting of alfalfa is usually lower in phosphorus than later cuttings are.

One hundred pounds of potash to the acre has given profitable increases in yield on most soils.

\section{Lime in Subsoil is Available to Alfalfa}

In another experiment, where there wasn't enough limestone in the soil surface, W. H. Pierre mixed some limestone with the subsoil at depths of 16 to 24 inches below the surface. Result? The yield of alfalfa jumped as much as 4283 pounds per acre. Of course it is not practical to pump the subsoil with lime, but the experiment goes to show that if limestone is naturally present in the subsoil, it will become available to deep-rooted plants like alfalfa. That means that less will be needed in the surface of such soils.

\section{Nitrogen Is Needed in Legume-less Rotations}

Your crop rotations - are there legumes in them? If not, it will pay you to fertilize with nitrogen. That's what our soils scientists, W. H. Pierre, G. G. Pohlman, and T. C. McIlvaine, found after eight years of trials at the Lakin Experiment Farm in Mason County.

In a rotation of corn and wheat, where we applied 500 pounds to the acre of an 0-12-4 fertilizer, we got 27 bushels of corn. The same amount of a 4-12-4 fertilizer stepped up the production to 48 bushels. And when we made it 8-12-4, the yield went to 76 bushels.

And what about sweet clover as a green manure crop in the wheat? That legume increased the corn yield from 27 to 67 bushels to the acre. In other words, the sweet clover boosted the corn yield 
about as much as 175 pounds of sulfate of ammonia did. And in rotations with legumes like red clover, we found little response to nitrogen fertilizer. These figures are for 1937.

Adding nitrogen to wheat has proved its worth in cropping systems lacking in legumes. In some experiments the wheat yield has more than doubled when 200 pounds of cyanamid was applied in the spring. And when it comes to timothy sod, top dressings of cyanamid, at 100 pounds per acre, have bettered the hay yield by a half ton.

\section{FRUIT AND VEGETABLE CROPS}

THE SCOPE OF RESEARCH in horticulture must necessarily be

1 wide and diverse because of the vast and varied number of plants to be studied for their response to different cultural treatments. Also, horticulture and its products have the interest of every person in the State, whether he has a couple of flower pots, a home vegetable garden, or a commercial apple orchard.

\section{Apple Roots Go Deep in Limestone Soils}

How deep do apple roots penetrate? That depends on the soil, but in practically every case investigated in West Virginia, they reach bedrock. In a four-year study, now completed, of rooting on orchard soils, L. P. Batjer and R. H. Sudds found that apple roots go down as much as 10 feet in the deep limestone types of the Shenandoah Valley. On shallow shales it is a different story - in some cases only 18 to 24 inches. Besides their usual greater depth, the limestone soils can hold more water available for plants than the shales, for each foot of depth. For these reasons the limestone soils are generally superior to the shales in resisting drouth.

Beginning in the drouth year of 1930, a study was conducted to see if dynamiting and subsoiling would help hold water in shallow soils. Neither explosives nor Killefer subsoiling machines were effectual in encouraging deeper rooting under the experimental conditions which were representative of West Virginia orchard soils. Our horticulturists therefore recommend that deep but welldrained soils should be selected for new orchard sites.

Another phase of soil study has been a survey of 60 representative orchards in the Eastern Panhandle. On half of these orchards a detailed soil map has been made which shows (1) soil types, (2) topography, (3) erosion, and (4) drainage. This work is part of a 
project which will eventually establish guide posts to successful fruit growing in the future.

\section{What Form of Nitrogen is Best for the Orchard?}

Nitrogen is one of the principal needs of a farm crop, but pure nitrogen, which is a gas, would do the plants no good. Instead, this element, like all other elements necessary for plant or animal growth, must first be changed into a form which plants can use for food. That is what the farmer gets when he buys fertilizer. Some of these are called nitrogen carriers, others phosphorus carriers, and so on.

For three years, various carriers of nitrogen have been tried by R. S. Marsh and R. H. Sudds in an investigation of orchard soils in Berkeley County. The greatest response in growth came from nitrate of soda and from ammonium sulfate, urea was intermediate, and calcium cyanamid gave the least response. The yields of fruit so far show little difference. In an orchard in Jefferson County, development of small-sized roots was $50 \%$ greater where the trees received sodium nitrate for 11 years than where ammonium sulfate was used for the same length of time, and the soil acidity in the former was much lower than where sulfate was used.

Although ammonium sulfate is cheaper than sodium nitrate, in some parts of the state it is recommended that in fertilizing their trees, farmers apply lime as necessary to correct the acidity which will be formed if the sulfate is used.

Investigations with potash fertilizer indicate that most West Virginia orchard soils have enough of this element to meet the present requirements of apple trees, although the amount is not so plentiful in the shale and sandstone soils. There is some evidence that indicates the need of potash on peach trees planted on the shallow shale soil areas.

\section{Apple and Sour Cherry Need Better Rootstocks}

So much for the soil around the roots. Now what about the roots themselves? From a long-time standpoint, one of the important needs of the fruit industry in West Virginia, as elsewhere, is improved stocks upon which to graft our commercial varieties. This need is more acute with the apple and sour cherry than with other fruits that are cultivated commercially in this State.

Since 1933, extensive field tests have been made by Leif Verner, L. P. Batjer, and R. H. Sudds, with several thousand trees in the heart of the State's eastern fruit-growing region. The experiment involves 35 stocks and ten varieties of apple, with other tests at Mor- 
gantown. Not all varieties of apples respond alike in growth and yield to the same lind of rootstock. Each variety must be tested on every stock to determine how the top and root get along with each other.

Trials with dwarfing stocks have not proved encouraging as a commercial proposition, although some of them may be adapted for back-yard orchards. In the case of a rootstock known as Malling 1, the Red Rome trees required propping, and Malling 9 was so weak that in a strong wind the trees would break off below the union. Also, mice show preference for the Malling 9 roots - a fatal weakness of that rootstock.

\section{What are the Best Varieties of Fruit?}

If you have not been able to get good color with the old standard varieties, try some of the new red sports. Otherwise do not use them. Few other changes are taking place in apple varieties. With peaches there are some promising new varieties that can be recommended because of their hardiness, quality, appearance, and season of ripening. If they fit into your system of orchard management and your season of marketing, varieties like Hale Haven and Golden Jubilee can be recommended without reservation, says R. S. Marsh.

In plums, cherries, or pears there seem to be no outstanding varieties to replace the old favorites for West Virginia conditions. But for black raspberry, generally prone to catch anthracnose, we have found at Morgantown that Naples is remarkably resistant to that disease. The Newburgh red raspberry is approved because of its all-around desirable qualities, and the Dorsett, Catskill, and Fairfax strawberry for quality and yield.

The best yields of the Eldorado blackberry were obtained by W. $\mathrm{H}$. Childs where the laterals were pruned to 12 -bud lengths and where nitrogen was applied, but the largest berries resulted when nitrogen was applied to plots pruned to 4-bud laterals. Nitrogen, by the way, matured the crop slightly earlier and increased the berry size and the yield in all cases except where the laterals were left unpruned.

\section{There is Profit in Blueberries}

We have native low-bush blueberries in West Virginia which are excellent piemakers; and there is a good market for them. Most of these are the size of small garden peas, but sometimes bushes are found with berries two or three times that size.

Blueberries grow naturally in nearly all parts of the State - often 
on abandoned fields or land that can't be cropped, and they are an important source of supplementary income to many farmers. Sometimes as much as $\$ 500$ is realized from the berries picked from no more than an acre of bushes. And that amount could be increased $100 \%$ if all bushes were of the superior types that yield large berries, as some plants do.

Blueberries are hard to reproduce and therefore are expensive. At the West Virginia Station we hope to work out ways of propagating the better species which will make the plants less expensive. Root, soft-wood and hard-wood cuttings, and tubering are being studied. Observations on the use of indole-butyric acid as an aid in root formation are also in progress. There is every indication that blueberry propagation will become a greatly simplified process, and that nursery stock prices will eventually be reduced considerably. W. H. Duis selected 47 plants for size of fruit, productiveness, cluster type, season of ripening, and hardiness. He took samples of soil in the various blueberry areas and is testing these samples for acidity and fertility.

\section{Some Peaches are Winter-resistant}

Many new varieties of peach, R. S. Marsh and W. H. Duis have found, are considerably more resistant to low temperature in the winter and early spring months than some of the older kinds like Elberta, J. H. Hale, or Belle of Georgia. Studies of cell-wall tissue gave no index of hardiness for certain tissues of the peach bud.

\section{But Tomatoes?}

Does it pay to harden tomato plants so as to make them frostresistant? E. P. Brasher tried this by putting hothouse seedlings in a cold frame before transplanting to the field. The results from a single season's trial gave smaller size of fruit, less yield, and delayed maturity. This experiment will be continued several seasons longer before definite recommendations can be made.

\section{Green Manures for Cabbage and Tomato}

It has been known for years that green manures add to the fertility of the soil. But how much? At the Lakin Experiment Farm in Mason County, K. C. Westover has experimented with green manure crops to study their effects in building or maintaining soil fertility. These were grown in rotation with vegetable crops, so that those green manures that can be seeded after the tomatoes and cabbages are harvested, are plowed under early in the spring. The work has 
not been in progress long enough to show important differences, but we find that continuous cropping with cabbage and tomatoes, with no additions of organic matter, is resulting in less vigorous growth and in reduction in yield.

In a Berkeley County experiment on a shale loam, the most economic returns followed 400 pounds per acre of 4-10-6 fertilizer applied in the row at the time of setting tomato plants, with an additional 400 pounds used as a side dressing.

\section{Use Complete Fertilizer for Potato}

Potatoes need a complete fertilizer. That is the lesson of a fouryear experiment carried on by K. C. Westover with numerous farmers in scattered sections of the State and on 12 soil types. This vegetable specialist found that 1400 pounds to the acre of high-grade fertilizer is not too much to spend on a cash crop. Larger yields, too, have resulted when he applied fertilizer in the drill rather than when he broadcast it.

\section{Many Vegetable Varieties are Tested Yearly}

No less than 280 varieties and strains of vegetable crops have been investigated at Lakin during the past two years by $\mathrm{K}$. C. Westover and E. P. Brasher, to obtain seedstocks better adapted to the climatic conditions and to the market requirements of the section. These include snap beans, bush lima beans, beets, broccoli, cabbage, Chinese cabbage, cauliflower, cucumbers, sweet corn, carrots, eggplant, melons, peppers, early and late squash, chard, potatoes, tomatoes, Brussels sprouts, peas, onions, spinach, and lima beans.

At Reedsville, in Preston County, where the Experiment Station, in cooperation with the Farm Security Administration, has carried on trials with field, vegetable, and small fruit crops since 1934, 122 varieties and strains of six kinds of vegetables are under test at Arthurdale. Details concerning these trials, which have been carried on at Lakin and Reedsville, are available to persons interested in specific phases of this work.

\section{Research in Floriculture}

When should carnation cuttings be taken for the plants to give the most profitable yield the following season?

To answer this question, A. P. Dye took cuttings during the winter of 1936-37 on the following dates - December 1, January 1, and February 1. The plants began blooming the following October. Those from cuttings taken December 1 and January 1 gave more 
blooms during October and November than did those from cuttings made February 1. However, the plants started in February gave their heaviest yield during the month of December, January, and February the following year. This cycle also repeated itself in the spring, with the February plants giving a heavy crop for Easter and Mother's Day. The total yields were: plants started December 1, 9 blooms; January 1, 9 blooms; and February 1, 13 blooms. With prices also higher at midwinter and at Easter and Mother's Day, the total returns were considerably higher for the plants started February 1.

\section{FORESTRY}

THE FOREST, one of the oldest habitations of man, is one of the 1 last to be considered as an asset to society, a resource which must be guarded against injury by disease and against destruction by fire or misuse; guarded and promoted, through an adequate program of research and extension, as the Nation's largest renewable resource and her best guaranty against erosion. I do not need to labor that point.

What has West Virginia done to maintain her forests? In the heyday of the lumber industry, the policy was "cut and clear out." There was no thought for the future. But it will surprise you, as it did me, that as long as 42 years ago, in 1896, a small group of men at West Virginia University were becoming increasingly aware that this raping of the State's forests must be stopped. In a meeting of the then new West Virginia Academy of Science these men called public attention to the fact, and urged public action - without avail.

Along about 1920 there was another attempt to influence public opinion in defense of the timbered wealth which still was falling to the axe. The State Farm Bureau, in convention during Farm and Home Week at the College of Agriculture, passed a resolution urging the Governor and the Legislature to look into the matter, even to the extent of raising funds for research in this field. In 1921 the State Government finally set aside funds for the creation of the State Game, Fish, and Forestry Commission, which became in 1933 the Conservation Commission, and since then, significant strides have been made toward preserving this very important resource.

In 1935 the College of Agriculture opened its doors to students desiring to specialize in forestry, and with the establishment of this course, which in 1938 became the Division of Forestry, the opportun- 
ity for research in forest problems, as they apply to West Virginia, has been offered. Let's see what's been done so far.

\section{What Is the West Virginia Forest Products Association?}

There are several cooperative associations operating in various states which are more or less successfully marketing the forest products of their members. Before this project was started, no cooperative corporation had been organized which had for its purpose the management of forest land. It would seem to be advantageous for owners of small acreages of forest land, especially absentee owners, if some organization existed which employed an experienced forest operator to manage timber land for the benefit of its members. In this way the small owner could profit by the assistance of a skilled forest manager and thus receive the advantages that only owners of large tracts have heretofore been able to obtain.

W. C. Percival, after an extensive survey, found that the owners of about 20,000 acres of forest land in Preston County were interested in a plan to organize a cooperative corporation for forest management, under flexible by-laws, so that plans of operation could be changed periodically, until a favorable type of organization should develop.

On June 28, 1937, a corporation was organized under the Agricultural Cooperative Marketing Act of West Virginia, and a charter was granted to it under the name of the West Virginia Forest Products Association. The Association began a trial operation on 40 acres of northern hardwood timber. This involved the formulation of cutting regulations, the marking of the timber to be cut, and the marketing of the products. A marketing agreement was made with a pulp company to handle the product at $\$ 10$ per cord plus $\$ 1$ bonus for the Association. Several cutting and hauling contractors were taken to the site of the operation, and their bids were accepted. As a result, contracts were executed in which the woods operators agreed to cut and move pulpwood, from the forest to the mill, at a total cost of $\$ 7.50$ per cord. The sales price of $\$ 10$ per cord was paid to the Association, and the difference between cost of operation and receipts, or $\$ 2.50$ per cord, was remitted to the landowner.

As a result of this trial operation, a policy has been adopted by the Association for the year 1938, like this:

1. A contract for the management of a definite acreage of land is made between a landowner and the West Virginia Forest Products Association which automatically makes the landowner a member of the Association.

2. A plan of operation of the member's land is formulated by the 
Association with the assistance of the forestry staff of the West Virginia Agricultural Experiment Station. This plan is discussed and verbally accepted by the member.

3. Cutting regulations in accordance with this plan are written by the Experiment Station forestry staff.

4. Tentative operating and marketing contracts, in accordance with the plan, are made between the Association and woods operators and timber buyers.

5. The operating contracts and the marketing contracts are presented to the Board of Directors of the Association and to the landowner concerned, and if accepted by both in writing, the contracts are placed in effect.

6. The woods operations are supervised by the Association.

7. The Association receives payment for their products when these are marketed, and pays each member the marketing contract price of his timber, less the costs of operation and supervision.

Changes may be made for operations during 1939. Two sawtimber cuttings are now in progress and we expect that bonuses received by the Association from timber buyers will cover the costs of supervision.

On January 1, 1938, the Association employed as land manager Mr. L. E. Lutz, who had had long experience in the cutting and marketing of forest products. It is his duty to determine the most practical way of handling each operation, to execute contracts in the name of the Association, and to supervise the various woods operations. The Upper Monongahela Valley Association has generously aided the Association in employing the land manager.

In order to formulate management plans and cutting regulations efficiently, the forestry staff of the West Virginia Agricultural Experiment Station has needed information regarding the volume and the growth of timber on each Association member's land. This requirement is being provided for by means of a forest survey undertaken through the joint effort of the West Virginia Conservation Commission, the U. S. Forest Service, the Appalachian Forest Experiment Station, the Agricultural Extension Service, and the West Virginia Agricultural Experiment Station. Approximately 40 men are engaged in making this survey on the lands of members of the West Virginia Forest Products Association in Preston County.

Volume tables, stated in terms of cords, were compiled during the trial operation undertaken in 1937. These will be useful in future operations on Association members' lands. A survey of timber mar- 
kets has been made by forestry staff members in order to aid the Association in the profitable disposal of its products.

\section{Some Tree Leaves Build Soil Faster than Others}

We have known for a long time that considerable differences appear when litter accumulates under different species of trees. But what are these differences, and how important are they?

In an attempt to explain these variations, W. H. Pierre, W. M. Broadfoot, E. A. Marten, and G. G. Pohlman have analyzed a very large number of mature tree leaves, to see how nitrogen, how organic matter soluble in water, and how "excess base" (excess alkalinity) affect the rate at which leaf samples rot. 'They did this with leaves from different tree species, and found that the rate of leaf decomposition was closely linked with the content of excess base. The rotting begins with attack by the fungi. Then the bacteria get busy. And so on until the leaf substance is returned to the soil, in which the tree derived its being and its location.

In this experiment, conifers, scarlet oak, beech, and sycamore showed the lowest content of excess base, and black walnut, black locust, yellow poplar, dogwood, sumac, and maples showed a much higher excess base over acid.

It is important to know what kinds of organisms tear down the dead leaves, because on this information must be based our knowledge of what organisms abound in soils of the forest. That is what some of our forest experimenters are working on now, classifying the fungi and the bacteria in different leaf litters, and determining the value of these organisms to the soil for future tree growth.

\section{AGRICULTURAL CHEMISTRY}

HEMISTRY, you know, is a fundamental science. It deals with what things are made of, and how they are made. Of all the occupational pursuits, agriculture is the most diverse in its make-up and it takes in the most territory. Farming is essentially a productive industry. Soil, air, rain, and sunshine are its raw materials; fruits, meats, grains, milk, vegetables, forage, and fibers are its finished products. Transforming these raw materials into finished products is in keeping with the laws of chemistry, and these laws are demonstrated in the nutrition and the growth of plants and animals. It is the business of agricultural chemistry to study, to understand, and in 


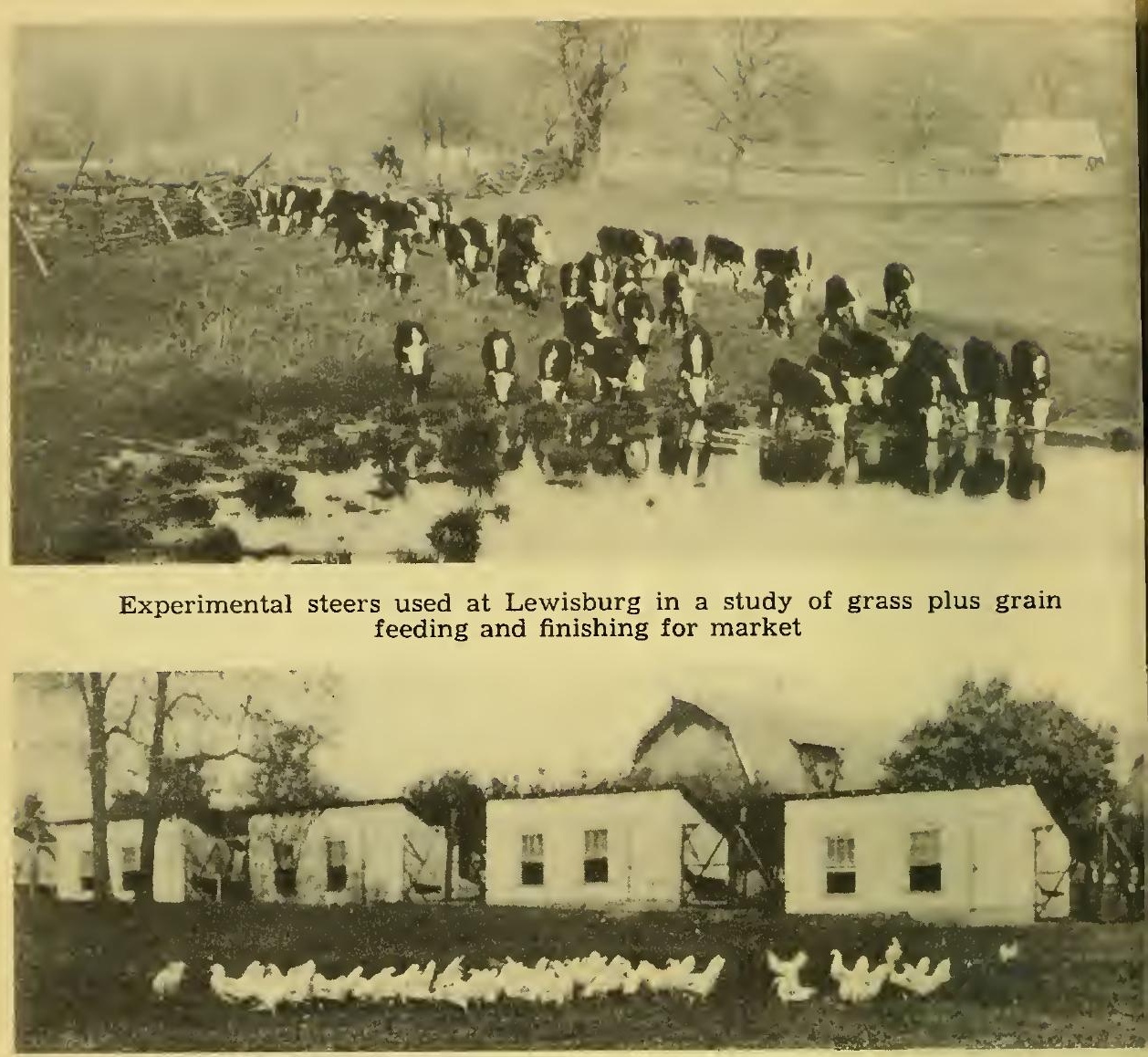

Years ago Horace Atwood experimented with White Leghorns at Morgantown

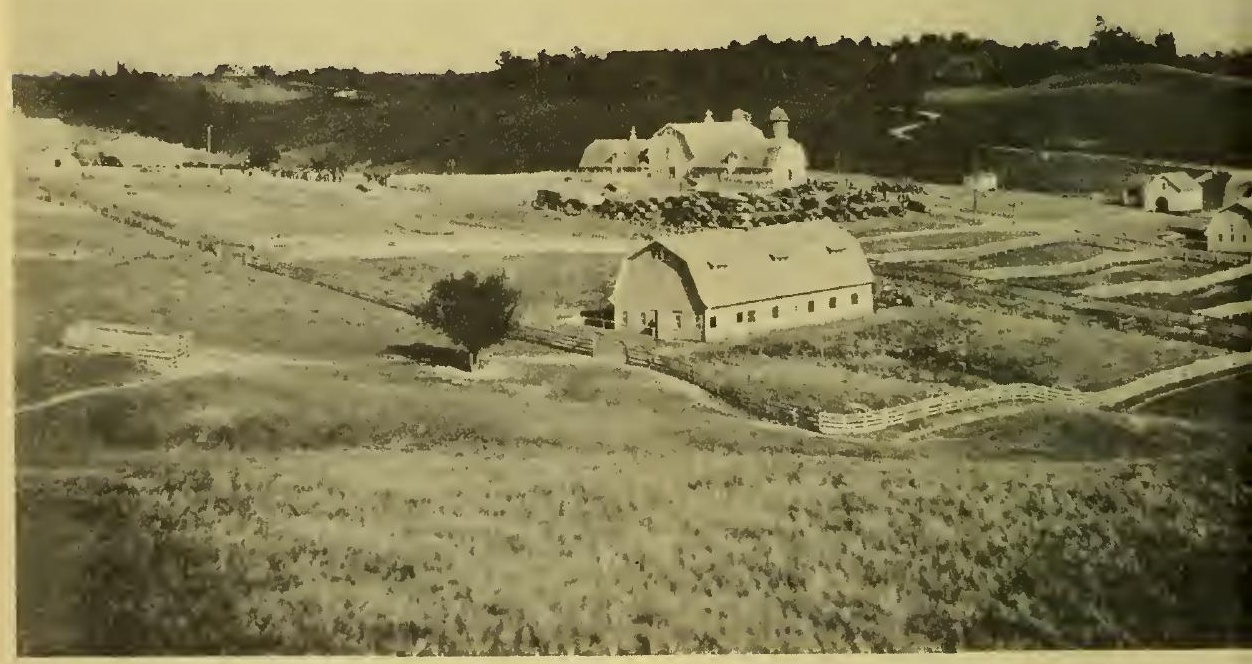

The Animal Husbandry farm at Morgantown

The hog barn

The beef cattle barn

The horse barn The sheep barn 



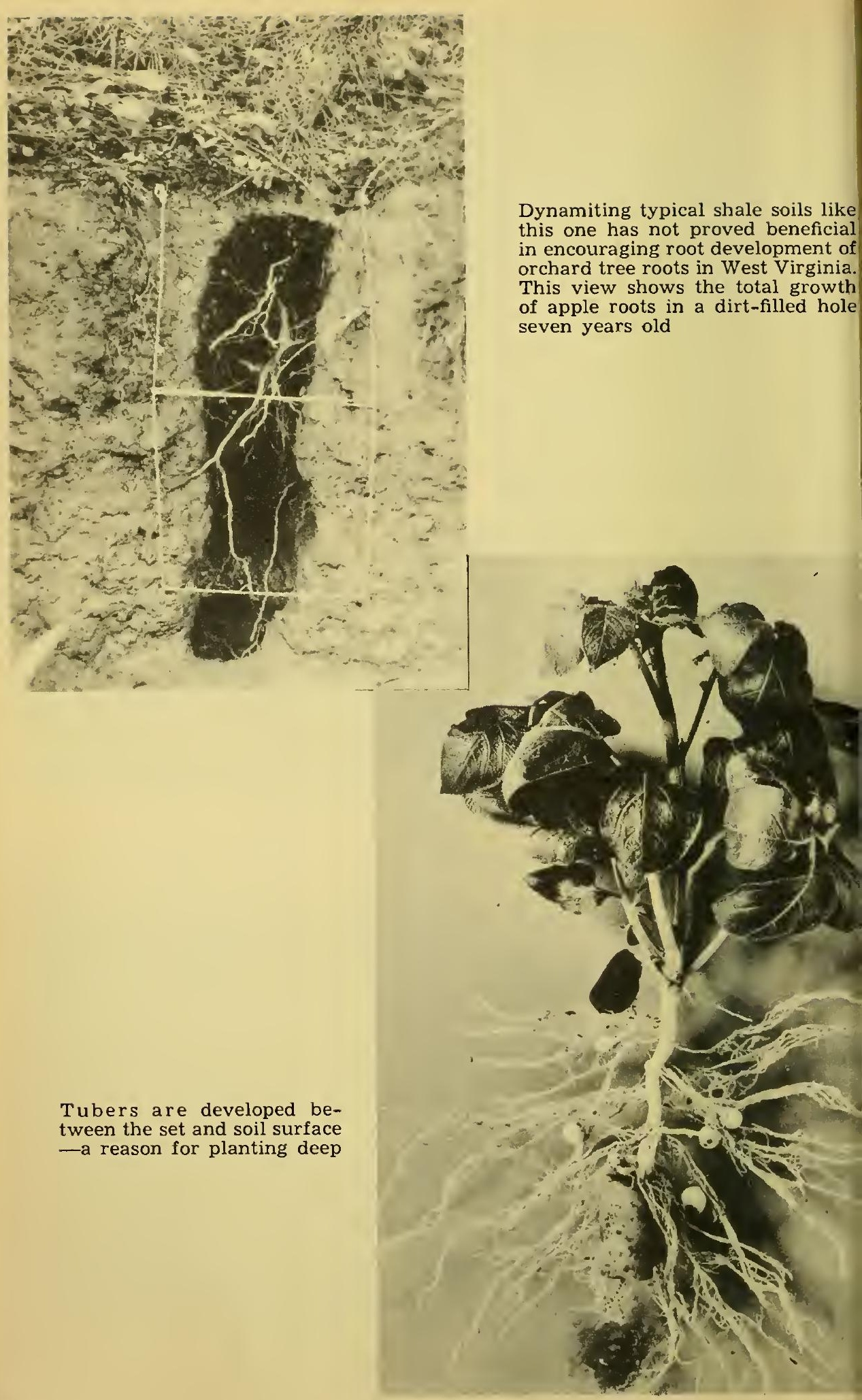



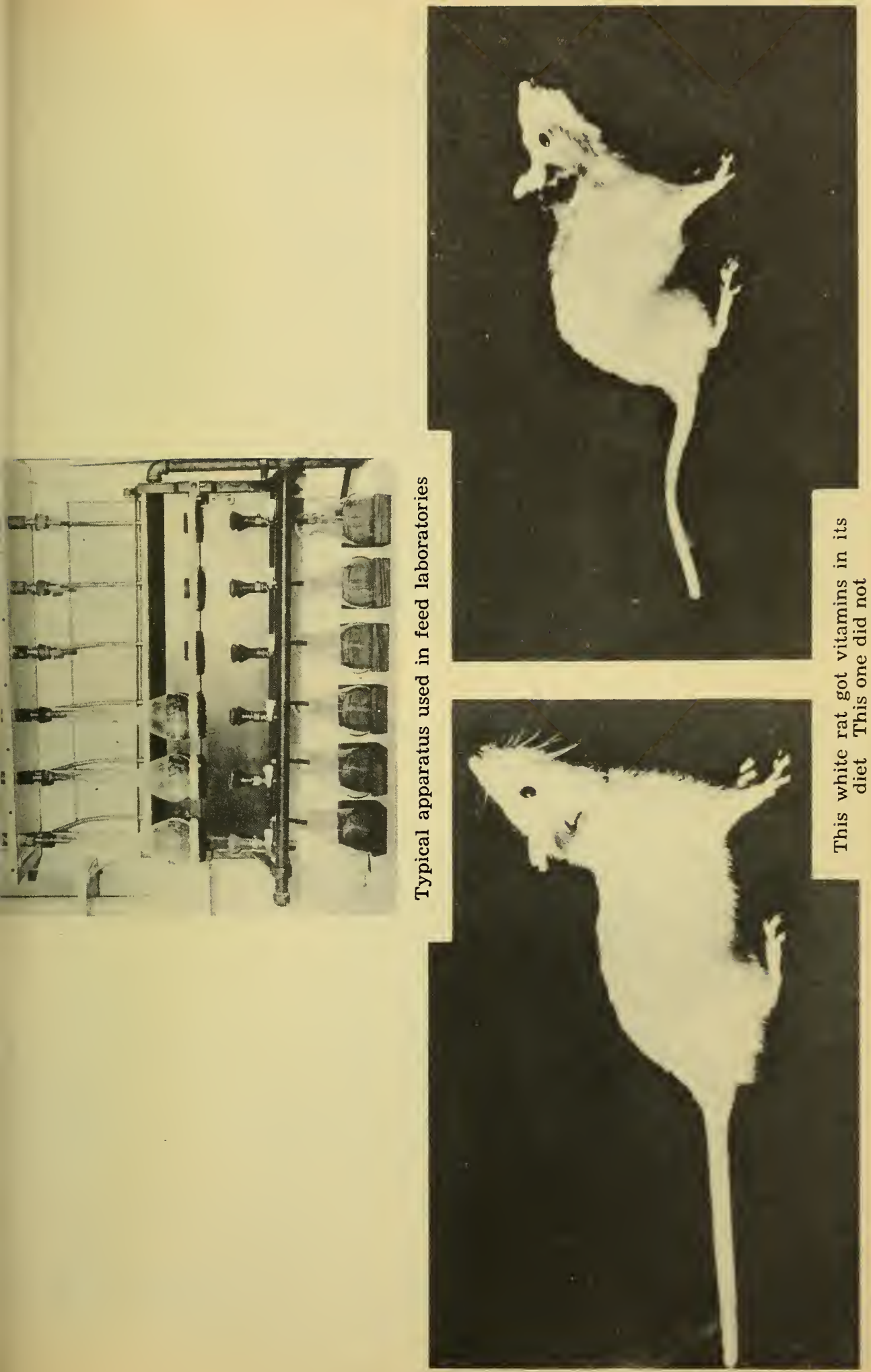

West Virginia

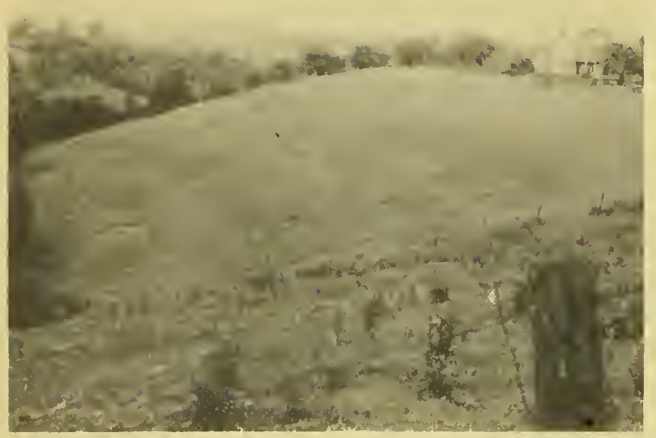

Before

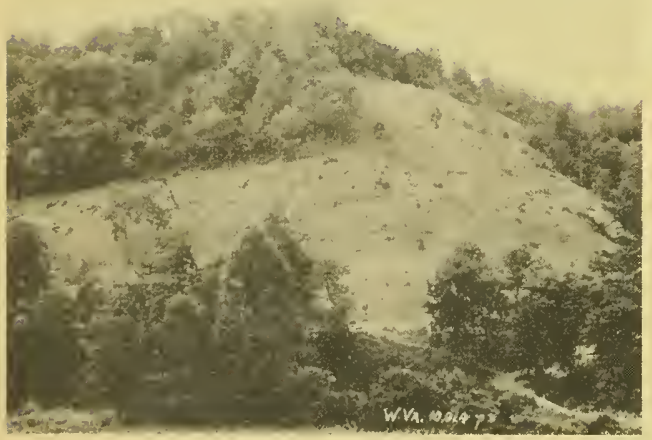

Sheet erosion encourages gully formation

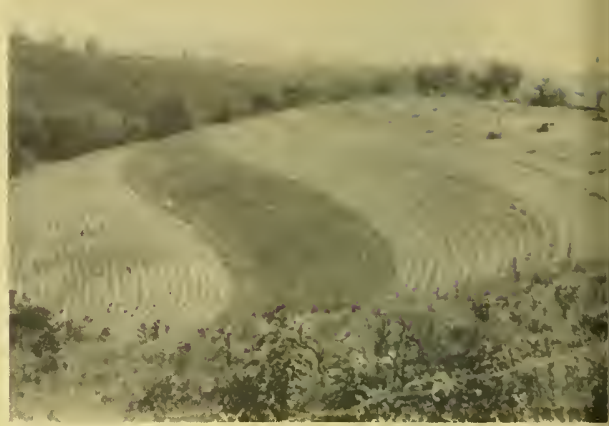

After

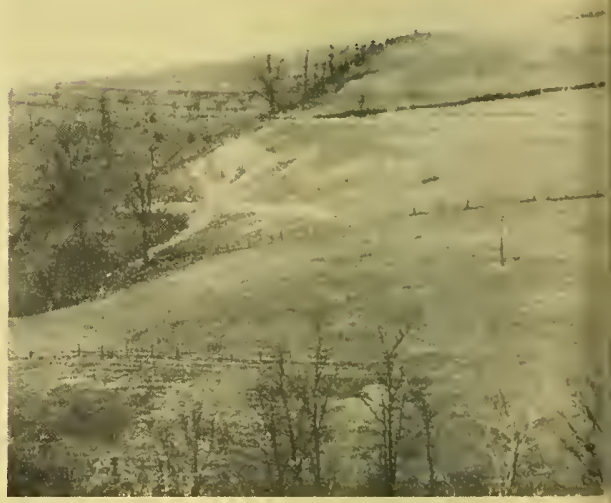

Land like this should never be cleared

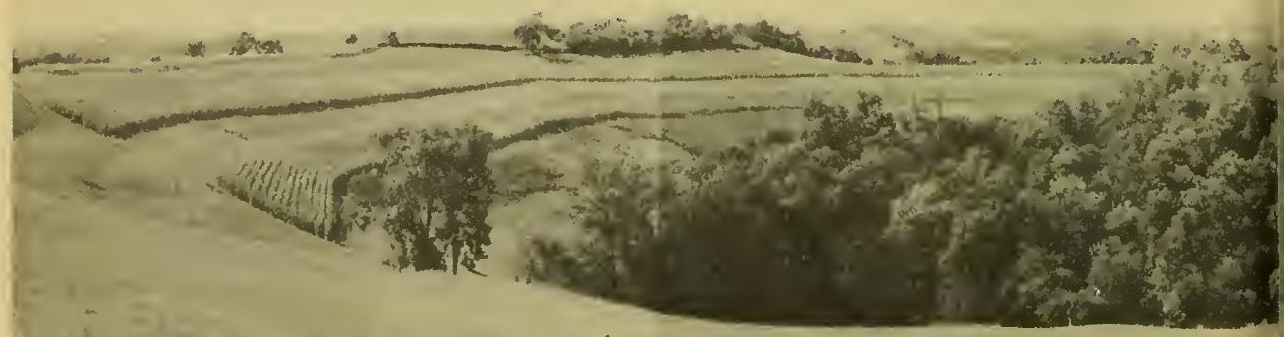

One of the end products of Soil Conservation 
part to control the chemical reactions that take place in plants and animals.

\section{Can We Influence Color in the Apple?}

Ordinarily we do not associate cranberries with Winesap apples, but did you know that the red color of both is due to the same coloring matter?

Two of our chemists, I. J. Duncan and R. B. Dustman, have been studying this color business for several years. They have pared and steeped many, many bushels of Winesaps in a method which reminded me of jelly-making time. After extracting the color from the peelings - and it took huge quantities of apples to produce a spoonful of residue - they studied this color substance in numerous ways, and after many trials they finally isolated it in pure form. The pigment is called idaein and belongs to a group of plant pigments known to chemists as anthocyanins.

So far, so good. We know what gives some Winesaps those red cheeks. But how can we encourage the tree to produce apples of a uniformly red color?' We know that sunshine is a factor in bringing about color in apples, but it seems probable that other factors are also concerned. Our chemists took their problem to the orchard and began to investigate the factors responsible for the development of this substance. The treatments have included (1) spraying the leaves, fruits, and branches of trees with various chemicals; (2) injecting solutions of different chemicals into the branches; (3) applying materials to the soil under the tree spread; and (4) binding, girdling, and defoliating at different times and in varying degrees. All these treatments are preliminary. We hope for definite ideas on the most promising method of approach to the problem of influencing color development in the orchard - and we still have a long way to go.

\section{It Takes Chemistry to Find the Coumarin in Sweet Clover}

Over in the Crops section of this epistle I mentioned the work in plant breeding by which we hope to establish a strain of sweet clover with low coumarin content. To do that, we have to know something about the coumarin. A few years ago I. J. Duncan developed a shortcut method for determining the percentage of this bitter substance in a sample of hay. Duncan has further improved his method and has applied it to such household gods as vanilla extracts, where coumarin sometimes is found as an adulterant or as a reinforcing agent.

This piece of research is a fair sample of the various ways in 
which a highly technical chemical procedure may serve different purposes. The plant breeder, the livestock feeder, the control chemist, and even the housewife may benefit from the improved method developed at this Station.

\section{Better Apparatus for Official Feed Testing}

Years ago, the Experiment Station had charge of testing commercial feeds and fertilizers in the State. Later the State Department of Agriculture at Charleston looked after this important service, but at the same time the Experiment Station busied itself with finding short cuts in the methods for determining this analysis. Farm feeds, you know, are highly complex chemical compounds.

For many years C. E. Weakley, Jr. - and others like B. H. Hite and $T$. B. Leith - have been introducing and testing out improvements in apparatus for analyzing commercial feeds. After several years, during which the successful operation of his apparatus was demonstrated repeatedly, these improvements have been published, and the response from chemical workers in other laboratories the country over shows their interest in our chemical research. These pieces of apparatus simplify the procedure of carrying out the official methods (recognized in all the states) for the determination of fat, protein, and crude fiber. While they were designed originally for the feed-control work, they are indispensable in many lines of research, especially in agriculture.

\section{Black-walnut Meats Can be Kept Fresh}

All of us enjoy munching black-walnut kernels on a winter evening - that is, if they are sweet and fresh. Nobody cares for them when they get rancid. About six years ago Nat T. Frame, who was then Director of Extension, asked R. B. Dustman, the Station chemist, how to keep walnut meats from becoming strong and ill-flavored before they could be used. The Boys' and Girls' Clubs of the State had been collecting and marketing considerable quantities of this product, but some of the buyers found it difficult to keep the kernels sweet and palatable. This was true particularly of kernels that had been kept on hand for some time, and more especially when those held during the warm months of summer became unfit for use.

Dustman found no literature on the subject so he tried different ways of storing the nut meats. Some he put in air, some in carbon dioxide gas, some in hydrogen, some in nitrogen, and some in carefully evacuated containers. Some were kept at ordinary cellar temperature, some in fruit storage ( 33 to 36 degrees F.), and some were 
held below freezing. At various intervals he withdrew samples and tasted them. After several years of trials this experimenter found that two factors are important in the keeping quality of the kernels: (1) absence of air (or oxygen), and (2) provision for cool storage conditions.

Storage in air-tight, air-free containers, either in a vacuum or in nitrogen, at temperatures near or below freezing, was successful in keeping the kernels in good condition over a period of several years. Kernels stored under these conditions for three years or longer could scarcely be distinguished by taste from those of the current season, and they were altogether palatable and acceptable. And here's a tip from the chemist: If you have no means of storing in nitrogen or in vacuum, pack only good, fresh, bright kernels, closely, in fruit jars, fill the jars completely, seal them tightly, and keep them in the refrigerator until you want to use them. If handled in this way, the nut meats will keep over considerable periods of time.

\section{PLANT PROTECTION}

YOU AND I might as well accept the verdict of universal experience, that, as civilization advances - or civilized agriculture for that matter - we have to put up with a growing army of insects and of plant diseases. All the more reason, then, why we should be on guard with a research program which will hold down the insect population and the disease factor to a point at least where either can be controlled with reasonably economical methods.

\section{Plant Pathology}

As agriculture becomes more intensive, the diseases of plants and animals become more important. A few generations ago, fruits and vegetables were grown successfully without spraying or other protection. Today, apples must be sprayed systematically and thoroughly before we can expect any high-grade fruit. And in potato production, diseases have become so serious by now that they are the most important single factor in that crop. This situation is developing with other crops of the field, the garden, and the forest to such an extent that some scientists predict that the control of diseases and parasites will be the most serious problem of the future agriculturist. 


\section{Black Rootrot is Highly Contagious}

It doesn't pay to plant young apple trees on the same sites where old trees have died from rootrot. This is a fungus disease and a powerful one: F. D. Fromme and F. J. Schneiderhan have made extensive investigations in the field. Forty or so trees were planted on each of four sites previously occupied by diseased trees. After three years of exposure to the organism in the soil, about 100 , or three-fifths of the 165 new trees, were found infected by the same fungus, some of them so badly that they could not have held their own another season.

In the meantime, in 1935, greenhouse experiments were carried out with some 28 different stocks of apple seedlings. These were planted in soil which had been inoculated with the rootrot organism. Every one of these seedlings became infected. From these field and laboratory trials we are convinced that the responsible fungus Xylaria mali - can live in the soil at least through two winters, and still be virulent enough to infect healthy trees. Incidentally, these forest trees can also be infected by the same fungus: hawthorne, redbud, black birch, Kentucky coffee tree, sycamore, dogwood, and black walnut.

\section{Fusarium Wilt Parasite is a Shifty Fellow}

Two strains of watermelons have shown a high degree of resistance to Fusarium wilt. One of these, the $760 \mathrm{~A}$ line from the Russian-Early Fordhook cross, is too late to mature melons of high quality. The other, Improved Stone Mountain, matures earlier but is not as sweet as the more susceptible types.

We are crossing these wilt-resistant lines with those varieties which possess high quality but which are susceptible to the disease. In this way we hope to improve the quality of the resistant type, or, to say it in other words, to put some wilt resistance into the strains that already are good-tasting watermelons.

The other side of the problems has to do with studying all of the peculiarities of the disease that has cost the farmers plenty in the Ohio Valley and elsewhere. A knowledge of these peculiarities is necessary to the success of the breeding work.

It so happens that the wilt organism - a Fusarium - is capable of changing its nature slightly under different conditions, and that new generations are not always like their parents. The result is a great variation in virulence among organisms causing wilt - that is, in their power to infect watermelons or other crops. This holds true also of other plant species, as we have found from greenhouse 
or laboratory studies of cotton, cabbage, tomato, banana, soybean, potato, sweet potato, cantaloupe, willow, strawberry, celery, dahlia, and dogwood. Nature seems to be breeding new disease-producing fungi almost as fast as our plant breeders breed new varieties of crops. If we can find out how nature produces these varieties of parasites and can slow down the process while we speed up our own selection and plant-breeding program, we can get quicker and more lasting results.

\section{When are Sprays Injurious to Fruit?}

High temperature and high humidity together are bad medicine for fruits when sprays are applied. Under such conditions an insecticide or fungicide spray, applied under pressure, will often injure either the foliage or the fruit, or both.

So F. J. Schneiderhan and C. F. Taylor have found out in a series of tests under a wide variety of conditions. Using a knapsack sprayer at a pressure of 125 to 150 pounds per square inch, they tested several sprays at different times on single branches of a great many apple trees. The rest of the tree told the story of how much injury was caused by the sprays under the different conditions. When enough information is obtained, our spray recommendations will be modified accordingly.

In another part of this experiment we have worked with cover sprays of Bordeaux 4-8-100 and with Fruit Copper Hydro in their effect on apple blotch. From an $81.5 \%$ infection on the check plots, the Bordeaux reduced the infection to $15 \%$, and the Copper Hydro reduced it to $6.5 \%$.

Still other work in this experiment has to do with the mechanical and chemical efficiency of different types of sprays applied at high pressures. Mosit of our tests are with lime-sulphur 1-50 in combination with arsenate of lead. We have to keep studying many sprays to find out whether they do any harm to the trees, while they are killing insects and diseases.

\section{Blue Stem of Potato a Fast Worker}

Just how fast a new plant disease sometimes works is shown in the case of potato "blue stem," which was first noted in the Appalachian region about eight years ago. This disease has spread so rapidly that it has forced some farmers in West Virginia to give up commercial potato growing.

Here's what happens: First you see a dwarfing, pale discoloration, and an upward folding of the leaflets at the top of the plant. 
The stems on the Rural variety take on a deep blue color. Seven to ten days later, the vines wilt and die. Brown spots and streaks appear in the flesh of the stems, tubers, stolons, and roots. Under the microscope you can see dead tissue in different parts of the plant.

What to do? That's what has us up a tree. We know (1) that the disease is not passed on through the tubers; (2) that there is more disease along the edges of a potato field; and (3) that such environmental factors as temperature, moisture, altitude, and soil type have no apparent effect on the prevalence of this new and threatening scourge. And we have proved to our satisfaction that it is not a bacterial or fungus disease. L. M. Hill and I have been working steadily on this problem. We have evidence that it is spread by insects. It is absolutely necessary that we find out what causes the disease before we can fight it successfully. That is just one of the many reasons why your State - like 47 other states - maintains an agricultural experiment station.

\section{The Plight of the Chestnut Tree}

The chestnut blight, which has destroyed nearly 100 percent of the commercial chestnut trees in the United States, is caused by a fungus which enters through wounds and works in the growing layer of tissue between the bark and the sapwood. After many years of observation we have found that an occasional chestnut tree has survived the blight and is still producing nuts. It is probable that these trees have some degree of resistance, and it is reasonable to suppose that some of the progeny of such trees would carry the resistance of the parent. We have therefore been collecting nuts from such trees for several years and have planted them on the Experiment Station grounds at Morgantown. We now have several hundred such seedlings and are experimenting with them to determine which ones are resistant. If we succeed in finding a resistant American Chestnut we shall hope to be able to find a satisfactory way of reproducing it and using it in restocking our chestnut stands.

\section{Why Study the Behavior of Fungi?}

For many years, scientists have been investigating the nature of all life, including its requirements for grawth and for reproduction. Years ago we heard much about calories and how important it was to have the proper number of these energy-producing substances in the different foods we ate. In more recent years, vitamins have proved their importance in the human diet - and even in the animal diet. Still more recently, science has found that there are still other ex- 
tremely small substances which affect life. These have been given the term "growth-promoting" or "sex-promoting" substances.

Now these substances, like the vitamins, are so highly complicated in their make-up that until recently it has been impossible to break them down into their chemical formulas and learn just what they are. But chemists recently have discovered the formula for several of the vitamins and have made them artificially in the laboratory. Now you can buy vitamins in tablet form from the local druggist.

We have not yet learned so much about the vitamin-like substances that control growth in plants and fungi, but progress is being made. For example, Miss Hazel Cameron has found that one of these substances in peas, stimulating for fungi, was also stimulating for mice, and behaved like one of the hormones of the ductless glands rather than like a vitamin. It is one of the important pieces of work of this Agricultural Experiment Station to study the behavior of fungi under a wide range and variety of conditions, both in the field and in the laboratory. Only by knowing all we can about these organisms, and how their growth is influenced, can we find ways to combat those which kill our crops or destroy our trees. We get at this problem in a very real way, in the laboratory, where we can study the fungus intensively by reproducing those conditions which help them to grow and multiply in field and forest. It is a long and painstaking piece of work that L. H. Leonian and V. G. Lilly are working on. Yeast extract, pea extract, and certain forms of nitrogen are playing a large part in this study. It is a study which we might call "pure science", but it is sure to have practical applications in the end.

\section{Insects}

In West Virginia, work in the field of entomology - that is insect study - is devoted mainly to studies of the biology and control of insects which are important in commercial orchards. Then, too, we are studying temperature in its relation to insect development, and we are testing the efficiency of various insecticides in the control of insects which attack garden plants.

\section{What Progress in Arsenic Substitutes?}

That there is nothing new under the sun never seems to be true when insects are the subject under consideration. Fortunately, it is no longer true of insecticides either. Since the fruit grower has been 
restricted as to how much poison he may sell along with his fruit he has been clamoring for new insecticides, for materials which will kill insects at 40 rods but which will be harmless to man. So the search for these materials, arsenical substitutes, has been going on at mad pace for several years.

Here, once more, progress is slow but not entirely lacking. Arsenate of lead still reigns as king of the poisons for insects, but several new combinations of this material have been worked out which result in less residue or in residue which is more readily removed than was formerly the case. New forms of nicotine have been developed by the chemists and tested in our experimental orchards; none of these will displace all the arsenate of lead from the spray program but some of them show promise of replacing part of it.

Rotenone, another product of a plant ("derris" is the name usually given to the plant and often to the product) has been substituted for arsenicals in much of the spraying for vegetable crops, but it has not yet been so successful for orchard insects. It is still among the strong contenders for a place in the orchard-spraying program, and with some modifications, rotenone might well prove to be just what we need.

Absolutely new a few years ago, and man-made, is phenothiazine, a non-harmful insecticide which has been very successful in the control of codling-moth in some orchards, but it has not given the even and certain results which we must be able to count upon for a widelyused insecticide. Chemists are still working on the defects in the material, and tests of its insecticidal qualities will be continued so long as there is any hope that it can be made into the long-sought insect poison that is harmless to man and to plants. Numbers of other materials might be mentioned, but, until they are nearer ready for grower use, it would scarcely be worth while.

For other insects than the codling-moth the search for new and better insecticides goes on. The plant lice that attack apple, and the pistol case-bearer, a major threat of a few years back, still occupy a part of the time of the investigators, L. M. Peairs and Edwin Gould, and the program for their control is improved more or less every year by new treatments, either those worked out at the University Experiment Farm at Kearneysville, or adapted to our conditions from programs worked out in other states. 


\section{The Timing of Sprays and the Weather Factor}

Mark Twain said that everybody talks about the weather but nobody ever does anything about it; insects, on the other hand, never talk about the weather, but what they do is usually very directly concerned with the weather. The time when they get restless in the spring depends on the weather; likewise the number of insects still alive often depends on the weather of the winter just passed. Just when the insects may be expected to become injurious will often be determined by the weather conditions of the season. More important to us, the time when the insects are least able to withstand any control measures which man may devise for their undoing will frequently be directly connected with the weather, possibly for several months before.

For these reasons, among others, the Station is accumulating, as fast as conditions permit, data showing how the many species of injurious insects vary in their behavior with the variations in the seasons. To a certain extent we are even now able to predict what will happen in parts of the insect world ahead of time, through our knowledge of these interactions. An important instance is in the timing of the applications of orchard sprays. Temperature records play a vital part in this service. As knowledge becomes more complete for a greater number of insects, we may learn how to time various other control practices in such a way as to make them most effective. The winter weather records, including records of soil temperatures, are forming the basis for estimates of the probable survival of some insects, so that we may know whether danger during the early season need be anticipated, or whether the population of insects is too low to do serious damage.

Continued studies, which do not require a great amount of time each year but which must extend over a period of years to cover all possible combinations of weather, are a part of the long-time program of the department of entomology. Some knowledge of the growth activities of plants must accompany the information on insects, if the complete picture is to be before us; records which tend to supply such knowledge accompany these studies. In rare instances only may we expect to control insects by the use of this information; we do hope, however, that such data will make our other control programs more effective and less expensive. 


\section{Big Bugs Have Little Bugs to Bite Them}

The problem of the fruit grower in West Virginia has been, for years, the codling-moth. He is Public Enemy No. 1 to the apple orchard. Other pests wax and wane but the codling-moth is always abundant. Control of this orchard gangster requires lots of poison, and that poison is responsible for the residues to which so much objection has been raised in recent years. While the search for less objectionable poisons continues it has seemed wise also to try other means of control; methods that are not based primarily on the use of poisons.

One of the open secrets in professional insect control is to let nature do some of the controlling. Usually we don't happen to hear much about this form of control, because it isn't spectacular. We do know that the codling-moth has a few public enemies too, and fortunately for the apples, these enemies have been getting more important. Parasites and predators, we call them.

Studies of what happens in the life of the codling-moth have furnished much information which we are attempting to utilize in an entirely new sort of control program. It is well known that the fullygrown codling worms crawl into any suitable crevice to hide while they transform to moths. Ordinary corrugated paper furnishes ideal hiding places, and a large proportion of the worms will crawl into the little tubes in such paper when that is arranged in the form of narrow bands around the trunks and branches of trees. In these bands the worms may be destroyed by poisoning the bands with "beta-naphthol" and other chemicals; or they may be removed from the trees and killed otherwise; or they may be removed from the trees, and instead of being destroyed they can be placed in cages and allowed to develop.

In the new cooperative project the latter practice is followed. The fully-developed insects cannot escape from the cage back into the orchard; the tiny parasites which may have been in the worms can, and do, get through the screen of the cages and carry on their work with other worms that have not yet been killed or captured. But in the normally-treated orchard, when the larvae are killed which are infested with the parasites, the parasites die also; so it is easy to see why the caging program might be expected to give the best results.

Many insects other than parasites kill the apple worms; ants are quite important in this way, and no one yet knows how many other insects do so or what the relative importance of all of them may be. In this project we are seeking full information on these and many other points; we are, at the same time, studying how to establish, 
in the orchard, conditions which will attract and maintain the greatest possible number of codling-moth enenies of all possible sorts.

When we have succeeded in doing this we may find that the amount of spraying required to give good commercial control can be greatly reduced; maybe, entirely eliminated in some instances. Or we may find that the parasites and predators and the mechanical practices just won't do the work. It must be remembered that, if we knew beforehand what the results would be, the experiment would not be an experiment, but merely a demonstration. It is expected that this experiment must run for several years before conclusions can be drawn. So far, we feel every reason for an optimistic attitude toward the prospects.

\section{There Are Other Insects, too}

Every now and then, somebody reports a new outbreak of some insect, somewhere in the State. When that happens, it is up to us to trace that outbreak and to recommend control measures, or, failing that, to make preliminary tests of new treatments for such insects.

Then, too, there is a constant flow of new spray materials on the market. Of these we aim to test enough to learn something of their value. Many new insecticides are mixtures of derris, or rotenone, or pyrethrum. The pyrethrum compounds have shown promise for the control of the harlequin cabbage bug and the squash bug, and up to this discovery we had no treatment to recommend to you. Maybe this will prove effective in controlling the cucumber beetle, especially in smaller gardens.

Bean beetle control methods have been pretty well standardized by now into several effective types of material. Cost and convenience will likely decide the choice for you. 


\title{
NUTRITION
}

\section{The Effect of Vitamin-A Intake on Colds}

\section{Bone Growth in Vitamin-Deficient Animals}

CTUDIES by Miss Hazel Cameron in these two fields are com$\checkmark$ parable with the studies on substances for fungi (reported on page 34 ) in so far as the method is concerned. Miss Cameron, like many other researchers the country over, works with white rats in order to find out how different food substances affect the growth and development of the animals. Any results from these experiments can be related to the problems of both human and animal nutrition. For instance, she finds that rats kept on a diet lacking in Vitamin A drink and hold more water in the body than rats which receive a normal ration.

It is just possible that humans are affected the same way. It is much easier to experiment with rats than with people, so we first find how things affect rats, then apply the results later on human beings. Rickets is an example; the disease of bone which causes bowlegs and other deformities in babies is being studied in white rats by Miss Cameron, working with Dr. G. S. Dodds of the Medical School, to learn how to produce healing and to prevent deformity. The point here is that some types of research have to pass through many stages and uncover a great many facts before definite conclusions can be drawn which will benefit both the agricultural profession and human existence.

\section{AGRICULTURAL ECONOMICS}

\begin{abstract}
A S AGRICULTURE CHANGES, so does research in farm ecoA nomics. Significant adjustments have taken place in the character of research bearing on farm management and the economics of agriculture. Formerly we were concerned with the costs of production and the problems of marketing. Today we still are struggling with these problems, and we are confronted with others resulting from the changes taking place in the national farm scene. In recent years this Station has gone into the study of tax delinquency, farm mortgages, appraisals and assessments, sectional types of agriculture, agricultural conservation programs, and soil conservation. Let's look at each of these.
\end{abstract}




\section{Tax Limitations and Tax Delinquency}

In 1934 the federal Civil Works Administration gave us funds for making a record of tax delinquency in rural real estate in each county for the 5-year period from 1928 to 1933 . W. W. Armentrout tabulated the information from 33 selected counties. In 1928 the delinquent area totaled $6 \%$ of the area in these counties. By 1933 this figure rose to $22 \%$.

In 1932, you remember, the State Legislature adopted a constitutional amendment which classified all property into four divisions and which also limited the levies which could be assessed against real estate by State and local governments. This action lowered the tax levies on farm real estate by about two-thirds. Now, to find out what effect such a large tax reduction has had on delinquency, our Station economists undertook a new study in 22 counties. It was financed by the Works Progress Administration and took in all delinquencies from 1933 to 1937 . Field work was finished in the summer of 1938, but the data have to be summarized and analyzed. From them we hope to determine the more important causes of tax delinquency.

\section{Your Farm and the Farm Mortgage Situation}

Records of 19 years (1917 to 1935) of farm mortgages in 22 counties have been studied by W. W. Armentrout during the past two years with the help of the Works Progress Administration and the Bureau of Agricultural Economics of the United States Department of Agriculture.

Private individuals as well as national and State banks accounted for the largest percentage of the newly-recorded farm mortgages in West Virginia. In 1917 the combined loans of the banks and of individuals made up 95\% of the total recordings and in 1932 that figure was still as high as $74 \%$. Throughout the 19 years, individuals made the largest new loans. Up to 1933 the Federal Land Bank made 5 to $15 \%$ of the new farm-mortgage loans in the State, but in 1934 this agency made nearly half $(49 \%)$ of the loans. A year later the Land Bank dropped back to $20 \%$, and banks and private persons again led the field.

Between 1917 and 1932 the combined interest rate charged by all lenders fluctuated less than two tenths of 1 percent. In 1933 the reduced rate on Federal Land Bank loans brought about a lower average rate for all lenders. This influence continued in 1934 and 1935. The rate charged by each local lending group on new mortgages throughout the 19 years averaged close to the $6 \%$ maximum rate permitted 
by law. Federal Land Bank's rate was $1 / 2 \%$ to almost $1 \%$ lower than the average for all lenders.

Where does your farm fit into this picture?

In 1917 the size of new farm-mortgage loans was around $\$ 1900$. This figure moved gradually up to the high of $\$ 3250$ in 1919 . Since then, loans have decreased in size until in 1935 the average was $\$ 1550$.

\section{What is a Fair Basis for Real-Estate Tax Assessments?}

Whenever funds collected from real estate taxes are assembled and then distributed to minor taxing units, it is very important that assessments in the various taxing units be uniform. The state property tax in West Virginia is now a small item, but the distribution of secondary aid to schools as now administered requires uniformity in assessments if injustices are to be avoided. Secondary aid today is distributed to a county when it cannot maintain a certain minimum school system after it has laid the maximum levies permitted by law.

Valuation, as well as rate of levy, is a factor in the amount of funds raised by taxation. Other things being equal, the county with low assessments, as compared with true and actual value, will receive an undue amount of secondary aid in comparison with another county whose ratio of assessed values to true and actual values is higher.

The normal sales value, as arrived at by appraisers of lending companies when compared with the assessed value of some 1200 farm properties, indicates the inequality of assessments in the various counties of West Virginia. In Berkeley County the sample chosen by W. W. Armentrout showed that the county assessor's value averaged $62.5 \%$ of the normal sales value arrived at by the appraisers; in Cabell County it was $83.7 \%$; in Greenbrier County is was $42.7 \%$; in Harrison County it was $80 \%$; in Jackson County it was $50 \%$; in Lew is County it was $87 \%$; in Tucker County it was $99 \%$; and in Upshur County it was $74 \%$. Other counties for which data were obtained fluctuated within these limits.

I repeat what we said in our report two years ago: the normal market value is a fair basis for assessments for taxation.

\section{Upshur County, U. S. A.}

Did you know that hilly Upshur is one of the nine counties in the United States in which an experimental AAA conservation program was established in 1938?

This program in the West Virginia county puts particular emphasis on pasture improvement and it centers largely around the use of lime and superphosphate. The object is to try out a program which 
holds better promise of meeting the needs of farmers in the livestock grazing areas of the state.

In building this experimental program, an effort was made (a) to keep it simple, so that all farmers might readily understand its provisions; (b) to depart from the usual AAA program only at a few key points, so that we might measure the effectiveness of the changes; (c) to assure that farmers might not receive decreased payments under the plan; and (d) to make it easy and economical to administer. We feel that these purposes have been accomplished in the program which we adopted.

Because a supply of lime and superphosphate is essential to the success of the program, provisions were made whereby farmers could obtain these instead of cash payment.

The observation phase of the program is now under way. A study is being made of the results of this experimental program as it compares with the State AAA program in similar counties. The project, under the direction of F. D. Cornell, Jr., is cooperative between the Experiment Station, the Bureau of Agricultural Economics of the United States Department of Agriculture, and the Agricultural Adjustment Administration.

\section{Is Soil Conservation Proving Its Worth?}

In seven widely-separated areas of West Virginia, the farmers and the Government together are reshaping the face of agriculture. You know the old picture - square fields of corn or grain over the hillside; fences running straight from bottom to top; pastures rutted with cowpaths along which erosion can get a toehold. 'The new soil conservation is changing all this. In these demonstration areas, stripcropping and contour-furrowing are the order, and the fences follow the lie of the land.

What does the Experiment Station have to do with this?

From about 1100 farms, E. C. Weitzell has been collecting information for measuring the progress in soil conservation. This study was for the years 1936,1937 , and 1938 . So far the results show that the farmers in these areas - Spencer, Moundsville, Ripley, Union, Lewisburg, Leading Creek, and Nutters Fort - are making a real effort, with the limited funds at their disposal, to work with the Soil Conservation Service in following improved methods for conserving the soil fertility and building it. More and more, as they see the good results on their neighbors' farms, the farmers are adopting the practices of using lime and fertilizer, growing legume forage, and following such practices as contour cultivation and crop and pasture rota- 
tions, in order to increase and maintain the income-producing capacity of their farms. In many places the low-producing grains, which do not give enough protection against erosion, are on the way out. Their place is being taken by legume forages that can produce better yields.

Another thing. On many farms of all types - especially the small, self-sufficing farms - we found a very low crop yield. This indicates a very real need for farm practices that will build up the fertility of the soil. Crop and pasture yields directly affect farm income and the farmer's standard of living.

To us - and that goes for the Extension Service too - it is plain that a well-planned program of conservation of soil and of water, a program that can be applied to each farm separately, will improve the agricultural resources of the whole State. But many small farms do not have the financial resources that are needed to make extreme changes and costly improvements. That is why this conservation program must be worked gradually into the present farm practices everywhere, without requiring radical changes in the production program of the farm.

\section{Orcharding Can Be Profitable}

M. A. Abrahamsen and R. S. Marsh have been looking into the factors which account for profit or loss in the orchard business in the Eastern Panhandle. They find three distinct types of operations: (1) "orchard" farms are large-scale holdings used entirely for fruit production; (2) "orchard \& general" farms are family-sized affairs which specialize in fruit production but which go into general farm operations on the side; and (3) "general \& orchard" farms. These, too, are family-sized farms which specialize in general farming but grow some fruit as a sideline.

Now, in order to measure the ways in which these 3 types compared or differed, we divided each type into four groups, according to labor income. By labor income I mean the amount of money you have left for your own labor after you have subtracted from your receipts all current expenses as well as the interest on your investment.

We found a large variation in net returns per acre, according to the type of farm and according to labor income. Here are the figures - on the most profitable fourth of the 88 orchard farms studied, the returns averaged $\$ 110$ per acré of bearing fruit; on 85 orchard \& general farms, $\$ 81$; and on 66 general \& orchard farms, $\$ 32$. In the least profitable fourth of these groups the average figures show a minus return of $\$ 4, \$ 5$, and $\$ 2$ per acre, in the same order. Our analysis 
shows that net income is closely linked with production per acre and with type of soil.

We feel that we should get more detailed information about the economic forces which influence the income from the orchard. What is the relationship of orchard income to factors like receipts per acre; expenses per acre; type of soil; climate; age of trees; variety of trees; cultural practices; marketing policies - ? We are studying these problems further.

\section{Feeds Rank First in Cooperative Buying}

In 1936 there was one and a quarter million dollars worth of cooperative buying among West Virginia farmers. 'That is, through purchasing associations. M. A. Abrahamsen's studies show that a little over $\$ 1,000,000$ in business was performed by the Cooperative Farm Services at Clarksburg. Half of this went through that association's 14 branch warehouses, and half through local county farm bureaus, informal groups of farm buyers, and private dealers. The other $\$ 250,000$ of the State's total showed up in sales by three independent cooperative marketing associations, six lime cooperatives, and six cooperative marketing associations handling farm supplies as a sideline.

How were all these purchases divided? Well, feeds took nearly half of all the cooperative supply business, and fertilizer took onefourth. All the rest was in general products, of which the most important were seeds, household supplies, electrical equipment, farm machinery, and building materials.

The purpose of this study is to look into the policies of organization, of business practices, and of management and control, in order to establish standards of operations which may be useful to all cooperative purchasing associations. We hope that an analysis of these problems on the economic basis will furnish information which will enable associations to appraise their business policies as these are associated with organization, purchasing and selling, credit, financing, membership relations and education, and management.

\section{How Much Food do We Grow at Home?}

Two years ago W. W. Armentrout and R. H. Fletcher went into three counties to study the habits in food consumption on the farm, and to find out how much of the total food consumed was produced at home. They found that for 89 farm tamilies in Braxton, the farm supplied $\$ 348$ worth of food and fuel. In Calhoun it was $\$ 286$ for 61 families, and in Doddridge, $\$ 347$ for 61 families. All these figures are 
averages of course. These 211 farm families averaged $\$ 476$ in food and fuel used per family of 4.8 persons. In other words, about threefourths of their food and fuel came from their own farms - and almost half of the food was provided by the dairy cow.

It seems that there are real deficiencies in the food supply of these farm people. For instance - not enough leafy and green vegetables, especially in winter. Not enough root vegetables. And not enough milk, especially among families with growing children.

Mimeographed Circular No. 31 of this Station analyzes these records in detail.

\section{Do You Know Your Milk-Production Costs?}

What does it cost to produce milk on West Virginia farms? If you can answer that question for your own farm, you are getting somewhere. Personally I believe that farm production is so complicated that it is impossible to arrive at the actual cost of production for any one commodity. You have to allow for a value for calves, a value for manure, and possible increases in the value of your cows. How do you know that any of these values are fixed? Against that you have to charge yourself the value of grain and forage grown on your farm, the value - or let us say the annual depreciation - of all your buildings and equipment used in the dairy enterprise, the interest on your whole investment, and finally, the out-of-pocket cash for feed and supplies bought. And that last-named item is the only actual cost you can count on. All the other factors are estimates. So what?

Our economists knew all this when they sent L. F. Herrmann to study costs in the Charleston and Huntington and other milk sheds. By reducing all the non-fixed costs to a fair basis of comparison between farms and between milk sheds, and after allowing for the proper market values of calves, manure, etc., they found that near Huntington, the average cost of production for 16 farms was $\$ 1.94$ per hundred pounds of milk at the farm. In the Charleston area, 20 farms averaged $\$ 1.97$.

The average production per cow - around 5500 pounds of $4 \%$ milk in both markets - was too low for most profitable production. Herds with high costs tended to have production below the average. Even so, they fed grain at the rate of one pound to every 2.4 pounds of milk, and the grain fed was too high in protein in relation to the roughage fed.

Half of a two-year study of costs in the Wheeling area has been completed. Thirty-nine herds averaged $\$ 94.91$ profit over all costs at the end of the first year, and the average return per hour of labor 
was $221 / 2$ c. The average size of herd was a little over 12 .

It seems that those herds with the highest returns were better managed in ways other than feeding. For instance, they had a larger number of cows freshen in the fall, so as to assure a heavier flow of milk when the price was highest. The herds with high returns kept higher-producing cows, and a few herds had special market outlets or grades of milk.

Cost records were kept on five Dairy-Herd Improvement Association herds during 1937. In comparison with the 39 Wheeling herds, the D. H. I. A. herds had higher costs per cow, but because their production rates were high, their costs per cwt. of milk were much lower. The Wheeling herd owners, you will recall, received $221 / 2 \mathrm{c}$ per labor hour. The herd-improvement herds returned 49c.

This year the economists are assembling all these cost records in order to throw some light on feeding practices. We are attempting to find the most profitable changes in the rates of feeding, in keeping with changes in the price of milk and of feeds.

\section{Volume Affects Distribution Costs}

Like the cost of production, the cost of distributing milk is a complicated subject. The Experiment Station began a study in 1933 of 22 dairy plants. A year later we turned to the farms and analyzed the distribution costs of 75 producer-distributors in four markets Clarksburg, Fairmont, Morgantown, and Wheeling. In 1936 we took in 67 producer-distributors in the Charleston, Huntington, and Parkersburg markets.

In this last study L. F. Herrmann found an average distribution cost of $\$ 1.94$ per cwt. of milk, or $4.17 \mathrm{c}$ per quart. On individual dairies these costs ranged all the way from $\$ 1.14$ to $\$ 5.87$ per cwt.

The volume of business had the most important effect on costs. A large volume helped to reduce these costs by increasing the labor efficiency and also the efficiency of trucks. Besides, a large volume helped to spread the fixed costs more thinly over the larger amount of milk distributed.

A few other factors have a bearing on labor efficiency. These are: the type of worker, the miles of truck travel, the amount of investment, and the average size of the milk unit sold. Truck efficiency was affected by the length of delivery route, the number of customers per mile, and the amount of milk sold per customer. 


\section{How Much Labor for Crop Production?}

Usually, in planning farm operations, the kinds and the amounts of crops to be grown depend either on the kind, the quality, and the amount of land available, or on the markets available. And very often, the farm plan must consider the labor requirements of these crops, by adjusting the crops to fit the labor available. That brings up two questions - how much labor, and when to apply it.

For many crops, labor makes up 20 to 25 percent of the total cost of production. Do you know the figures for your farm?

L. F. Herrmann, R. O. Stelzer, and W. W. Armentrout have gone in to this problem extensively and intensively by surveying 716 farms in 38 counties. They got records on the amounts of man and horse labor required for the different operations, such as plowing, fitting seedbeds, and planting - for each month of the year. Our Bulletin 286, "Labor Input on West Virginia Farms," tells the story.

\section{Twelve Types of Farming in West Virginia}

Farming in West Virginia breaks down into 12 distinct types. This term refers to an area in which farming is much the same as far as kinds and proportions of enterprises are concerned.

W. W. Armentrout has completed an extensive study of these types. The aim was (1) to get an understanding of the agriculture of the State as a whole; (2) to locate the different type-of-farming areas and to learn the nature of those "types" in terms of farm organizations, crop and livestock patterns, and sources of farm incomes; and (3) to identify and appraise the importance of the physical and economic conditions which have been and are now shaping the types of farming in the various areas.

There is too much to describe now. We plan to publish the results of this study sometime this winter under the title, "Types of Farming in West Virginia." You will probably be interested in it.

$* * *$
(Hanc epistolam
G. Jennius scripsit.) 


\section{STAFF CHANGES}

DROMOTIONS within the research staff during the biennium include G. A. Bowling, associate dairy husbandman; F. D. Cornell, Jr., associate agricultural economist; Edwin Gould, associate entomologist; C. R. Orton, director of the Agricultural Experiment Station; W. C. Percival, associate forester; G. G. Pohlman, agronomist; J. H. Rietz, animal pathologist; C. E. Weakley, Jr., associate chemist; C. V. Wilson, associate animal husbandman.

New appointments include L. F. Besley, associate forester; M. G. Brooks, assistant forester; M. L. Buchanan, assistant in animal husbandry; J. L. Cartledge, geneticist; W. H. Duis, assistant in horticulture; H. D. Erickson, associate forester; S. L. Galpin, hydrologist; E. O. Hamstead, assistant in entomology; T. Holsoe, assistant forester; W. K. Lanham, assistant in agricultural economics; J. G. Leach, plant pathologist; E. O. Leonard, assistant in agricultural economics; V. G. Lilly, assistant physiologist; R. S. Marsh, horticulturist; E. A. Marten, assistant bacteriologist; E. N. Moore, assistant animal pathologist; B. H. Schneider, associate animal husbandman; Edna D. Shaffer, assistant in agronomy; R. H. Sudds, assistant horticulturist; C. F. Taylor, assistant plant pathologist; E. H. Tyner, assistant agronomist ; L. G. Watson, photographer; R. O. Weibel, assistant in agronomy; E. J. Wellhausen, associate geneticist.

During the same period the following have resigned: F. D. Fromme, director of the Agricultural Experiment Station; W. P. Gainer, assistant in agricultural economics; R. J. Garber, agronomist; H. E. Knowlton, horticulturist; J. H. Longwell, assistant animal husbandman; W. H. Pierre, agronomist; F. J. Schneiderhan, associate plant pathologist.

W. E. Rumsey, for 45 years a member of the entomology staff, died on February 16, 1938. 


\section{PUBLICATIONS OF THE BIENNIUM 1936-1938}

\section{BULLETINS AND CIRCULARS}

Bul. 276. F. D. Cornell, Jr. Trends in West Virginia agriculturc. $80 \mathrm{pp}$. ill.
July 1936.

Bul. 277. H. O. Henderson, G. A. Borrling, and L. F. Herrmann. Amount of feed and labor used in raising dairy heifers. $28 \mathrm{pp}$. ill. Nov. 1936. (Out of print.)

Bul. 278. F. D. Fromme. Service to agriculture (Report of the West Virginia University Agricultural Experiment Station for the biennium ending June 30, 1936). 40 pp. ill. Dec. 1936.

Bul. 279. W. W. Armentrout. Charleston as a market for fruits and vegetables. 40 pp. Jan. 1937.

Bul. 280. W. H. Pierre, J. H. Longwell, et al. West Virginia pastures: Type of vegetation, carrying capacity, and soil properties. $56 \mathrm{pp}$. ill. Jume 1937. (Out of print.)

Bul. 281. L. F. Herrmann and G. A. Bowling. Milk-production costs in West Virginia: II. A study of the costs incurred by 36 farms in the Huntington and Charleston markets in 1935-36. 28 pp. June 1937.

Bul. 282. L. F. Herrmann. Milk-distribution costs in West Virginia: III. A study of the costs incurred by 67 producer-distributors in the Charleston, Huntington, and Parkersbuig markets for a twelve-month period during 193536. $28 \mathrm{pp}$. ill. June 1937.

Bul. 283. F. J. Schneiderhan. Preparation and properties of Bordeaux mixtures. 32 pp. ill. June 1937.

Bul. 284. G. G. Pohlman. Classification of land in West Virginia on the basis of use and agricultural value. $32 \mathrm{pp.}$ ill. June 1937.

Bul. 285. G. G. Pohlman. Land-class maps of West Virginia. 3 maps. Nor. 1937.

Bul. 286. L. F. Herrmann, R. O. Stelzer, and W. W. Armentrout. Labor input on West Virginia farms. $12 \mathrm{pp}$. Nov. 1937.

Cir. 72. H. E. Knowlton, W. H. Childs, and C. R. Orton. Growing raspberries in West Virginia. 24 pp. ill. Mar. 1937.

Cir. 73. T. B. Clark and H. M. Hyre. Turkey production: Suggestions for West Virginia. 24 pp. ill. Mar. 1937. (Out of print.)

Cir. 74. G. Heebink and H. O. Henderson. Feeding for profit in milk production. 22 pp. Sept. 1937. Cir. 75. R. S. Marsh and W. H. Childs. Fruit varieties for West Virginia. 20 pp.
ill. Feb. 1938.

Spec. Cir. Barberry Eradication office. Barberry eradication in West Virginia. 8 pp. May 1938.

\section{MIMEOGRAPHED CIRCULARS}

No. 15. Department of Agricultural Economies. Report on orchard practice study in Berkelcy, Jefferson, Morgan, and Hampshire counties, West Virginia. Sept. 1936.

No. 16. W. W. Armentrout. Labor incomes on Lewis county farms. Nov. 1936.

No. 17. M. A. Abrahamsen. The importanee of the Agricultural Conservation Program in West Virginia. Dec. 1936.

No. 18. M. A. Abrahamsen. The importance of the Agrieultural Conservation Program to farms in West Virginia: II. Applying ground limestone. Dee. 1936. 
No. 19. M. A. Abrahamsen. The importance of the Agricultural Conservation Program to farmers in West Virginia: III. Applying superphosphate fertilizer. Jan. 1937.

No. 20. K. C. Westover, T. C. McIlvaine, and E. P. Brasher. Varicty and strain tests of vegetable erops at the Lalin Experiment Furm during 19:36. Jan. 1937.

No. 21. M. A. Abrahamsen. The importance of the Agrieultural Conscrvation Program to farmers in West Virginia: IV. Seeding legtmes; V. Planting forest trees. Jan. 1937.

No. 22. K. C. Westover, W. H. Childs, and E. P. Brasher. Report of variety and strain tests of vegetables and small fruits during 1936 at the Arthurdale Experiment Farm, Reedsville, West Virginia. Feb. 1937.

No. 23. M. A. Abrahamsen. Some economic aspects of the Agrieultural Conservation Program in West Virginia. April 1937.

No. 24. E. C. Weitzell. Strip-cropping in northern West Virginia. Nov. 1937.

No. 25. K. C. Westover, T. C. MeIlvaine, and E. P. Brasher. Variety and strain tests of vegetables and small fruits during 1937 at the Arthurdale Experiment Farm, Reedsville, West Virginia. Jan. 1938.

No. 26. K. C. Westover, W. H. Childs, and E. P. Brasher. Variety and strain tests of vegetables and small fruits during 1937 at the Arthurdale Experiment Farm, Reedsville, West Virginia. Jan. 1938.

No. 27. M. A. Abrahamsen. A labor-income study of orchard farms in the Eastern Panhandle of West Virginia. Jan. 1938.

No. 28. C. R. Burnham. 1937 report of trials of field corn in West Virginia. Mar. 1938.

No. 29. L. F. Herrmann and G. Heebink. Dairy farm records. April 1938.

No. 30. L. F. Herrmann, G. A. Bowling, and Eldon Leonard. Milk-production costs in the Wheeling market, 1936-37. April 1938.

No. 31. R. H. Fletcher. The family living derived from the farm. June 1938.

\section{SCIENTIFIC PAPERS}

No. 164. A. H. VanLandingham, H. O. Hendersor, and G. A. Bowling. Studies on the chemical composit' on of the blood of dairy eattle: II. The effect of phosphorus intake or the calcium and inorganic phosphorus content of whole blood of dairy heifers during the period of first gestation and lactation. Jour. Dairy Sei. 19, no. 9:597-609. Sept. 1936.

No. 166. V. G. Lilly. Growth substances for fungi : Proc. W. V. Acad. Sci., Vol. 10: 95-103. Sept. 1937.

No. 167. C. E. Weakley, Jr. Fat-extraction apparatus for feeds. Ind. \& Eng'g. Chem., anal. ed. vol. 8:388. Sept. 15, 1936.

No. 168. C. E. Weakley, Jr. Special head for Kjeldahl distillation apparatus. Ind. \& Eng'g. Chem., anal. ed. vol. 8:367. Sept. 15, 1936.

No. 169. L. M. Thurston, W. C. Brown, and R. B. Dustman. Oxidized flavor in milk: II. The effects of homogenization, agitation, and freezing of milk on its subsequent susceptibility to oxidized flavor development. Jour. Dairy Sci. 19, no. 11:671-82. Nov. 1936.

No. 170. L. M. Thurston and W. C. Brown. The Minnesota Babcoek method applied to concentrated milk, chocolate milk, and ice cream. Ice Cream Field, Feb. 1937.

No. 171. W. C. Brown, L. M. Thurston, and R. B. Dustman. Oxidized flaror in milk: III. The time of copper contamination during production and processing, and acration vs. no acration as related to oxidized flavor development. Jour. Dairy Sci. 19, no. 12:753-60. Dec. 1936. 
No. 172. H. E. Knowlton. The effect of time of thinning on apple size. Proc Amer. Soc. Hort. Sei. 34:116-19 (1936).

No. 173. H. E. Knowlton. Experiments on the hardiness of peach and apple fruit buds. Proc. Amer. Soc. Hort. Sci. :34:23S-41 (1936).

No. 174. H. E. Knowlton. The winter hardiness of some woody plants. Proc Amer. Soc. Hort. Sci. 34:660-63 (1936).

No. 175. R. R. Robinson. Soil properties determining the hotanical composition of pastures in West Virginia. Jour. Agr. Res. 54, 12:877-97. June 15, 1937.

No. 176. W. C. Brown, L. M. Thurston, and R. B. Dustman. Oxidized flavor in milk: IV. Studies on the relation of the feed of the cow to oxidized flavor. Jour. Dairy Sci. 20, no. 3:133-45. Mar. 1937.

No. 177. F. J. Schneiderhan. Comparative toxicity studies with Instant Bordeaux and standard Bordeaux mixture. (In press.)

No. 178. C. E. Weakley, Jr., and T. B. Leith. Apparatus for crude fiber determinations. Ind. and Eng'g. Chem., anal. ed. rol. 9:194. April 15, 1937.

No. 179. C. R. Burnham. Differential fertilization in the $B t$ Pr linkage group of maize. Jom. Amer. Soc. Agron. 28, no. 12:968-75. Dec. 1936.

No. 180. R. R. Robinson, W. H. Pierre, and R. A. Ackerman. A comparison of grazing and clipping for determining the response of permanent pastures to fertilization. Jour. Amer. Soc. Agron. 29, no. 5:349-59. May 1937.

No. 181. W. H. Childs. Seasonal distribution of yield and size variation for some everbearing strawberry varietics. Proc. Amer. Soc. Hort. Sci. 34:364-67 (1936).

No. 182. K. C. Westover. The effect of sun-greening of potato seed tuhers on weight losses in storage and on subsequent field performance. Amer. Potato Jour. 14:11, p. 341-50. Nov. 1937. (Abstr. in Proc. Amer. Soc. Hort. Sci. 34:436. Dec. 1936).

No. 183. C. R. Orton and L. M. Hill. An undescribed potato disease in West Virginia. Jour. Agr. Res. 55, 2:153-57. July 15, 1937.

No. 184. L. H. Leonian and V. G. Lilly. Is heteroanxin a gronth-promoting substances Amer. Jour. Bot. 24, no. 3:135-39. Mar. 1937.

No. 185. R. R. Robinson and W. H. Pierre. The calcium and phosphorus content of pasture herbage and of varions pasture species as affected by fertilization and liming. Jour. Amer. Soc. Agron. 29, no. 6:477-97. June 1937.

No. 186. R. B. Dustman. Effect of certain solvents and of sequence of extraction from bone on the removal of fat and ash constituents. Jour. Assoc. of Offic. Agr. Chem., p. 469-475. Aug. 1937.

No. 187. R. B. Dustman and I. J. Duncan. Determination of coumarin in vanilla extract by a modification of the steam distillation method. Ind. \& Eng'g. Chem., vol. 9, no. 9:416-418. Sept. 15, 1937.

No. 188. W. C. Brown, L. M. Thurston, and R. B. Dustman. Oxidized flavor in milk: V. The effect of metal developed oxidized flavor on the iodine num. ber of the milk fat. Joul. Dairy Sci., vol. 20, no. 9, p. 599-604. Sept. 1937.

No. 189. G. S. Dodds and Hazel C. Cameron. Studies on experimental rickets in rats: II. The healing process in the head of the tihia and other bones. Amer. Jour. Path. 14, no. 3:273-296 (6 plates). May 1938.

No. 190. I. J. Duncan and R. B. Dustman. A comparison of the steam-distillation and alcoholic-extraction methods for the determination of coumarin in sweet clover. Ind. \& Eng'g. Chem., vol. 9, p. 471-474. Oct. 15, 1937.

No. 191. L. H. Leonian and V. G. Lilly. Partial purification of a vitamin-like substance which induces sexual reproduction in certain fungi. Amer. Jour. Bot. 24, no. 10:700-702. Dec. 1937 . 
0. 192. E. P. Brasher and K. C. Westover. The effect on yicld of hardening the tomato plant. Proc. Amer. Soc. Hort. Sci., 1937, p. 686-689.

o. 193. R. H. Sudds. Results with methods of deep-soil culture in W'est Virginia orchards. Proc. Amer. Soc. Hort. Sci., 1938, p. 295-301.

[o. 194. W. H. Pierre, Nelson Tully, and H. V. Ashburn. Determination of the equivalent acidity and basicity of fertilizers. Ind. \& Eng'g. Chem. (anal. ed.) 10:72. Feb. 15, 1938.

[o. 195. G. M. Browning. Changes in the erosibility of soils brought alout by the application of organic matter. Soil Sci. Soc. Proc. 1937: 85-96.

To. 196. W. H. Childs. Fruiting response of Eldorado blackberries pruned to varying lateral lengths with and without nitrogen fertilizer applications. Proc. Amer. Soc. Hort. Sci., 1938, p. 489-91.

Jo. 197. R. H. Sudds, G. E. Yerkes (U. S. D. A.), and W. S. Clarke, Jr. (Penna.). Growth and fruitfulness of three apple varieties on French crab seedlings and on a clonal stock. Proc. Amer. Soc. Hort. Sci., 1938, p. 363-68.

Jo. 198. R. H. Sudds, G. E. Yerkes (U. S. D. A.), and R. D. Anthony (Penna.). Orchard tests of mazzard and mahaleb cherry understocks. Proc. Amer. Soc. Hort. Sci., 1938, p. 415-418.

Jo. 199. R. H. Sudds and L. P. Batjer (U. S. D. A.). The effect of nitrate of soda and sulphate of ammonia on soil reaction and root growth of apple trees. Proc. Amer. Soc. Hort. Sci., 1938, p. 279-82.

No. 200. Leif Verner. A study of growth rates in Stayman Winesap apples. Proc. Amer. Soc. Hort. Sci. (1937) 35:128-31.

No. 203. C. R. Orton and L. M. Hill. Further observations on "blue stem" of potato. Amer. Potato Jour. 15, 3:72-77. Mar. 1938. 



\section{THE AGRICULTURAL EXPERIMENT STATION STAFF}

C. E. Lawall, M. S., E. M., Acting President of the University

C. R. Orton, $\mathrm{Ph}$. D.

Dean and Director

rohn C. Johnston, Chief Clerk

Gerald Jenny, M. S., Editor

\section{IGRONOMY AND GENETICS}

G. G. Pohlman, Ph. D., Agronomist

W. M. Broadfoot, M. S., Asst. in Agron.

J. L. Cartledge, Ph. D., Asst. Gen.

S. L. Galpin, Ph. D., Hydrologist

T. C. Mcllvaine, Ph. D., $\dagger$ Assoc. Agron.

Edna D. Shaffer, A. B., Asst. in Agron.

E. H. Tyner, Ph. D., Asst. Agron.

R. O. Weibel, M. S., Asst. in Agron.

E. J. Wellhausen, Ph. D., Assoc. Gen.

\section{NIMAL HUSBANDRY}

E. A. Livesay, D. Sc., Animal Husbandmail

M. L. Buchanan, M. S., Asst. In An. Husb.

T. B. Clark, M. S., Asst. Poult. Husb.

E. N. Moore, D. V. M., Asst. An. Husb.

J. H. Rietz, D. V. M., An. Path.

B. H. Schneider, Ph. D., Assoc. An. Husb.

E. T. Wightman, M. S., Asst. Poult. Husb.

C. V. Wilson, M. S., Assoc. An. Husb.

\section{YHEMISTRY}

R. B. Dustman, Ph. D., Agricultural Chemist

I. J. Duncan, Ph. D., Asst. Chem.

A. H. VanLandingham, Ph. D., Asst. Chem.

C. E. Weakley, Jr., M. S., Assoc. Chem.

\section{AIRY HUSBANDRY}

H. O. Jenderson, Ph. D., Dairy Husbandman

R. A. Ackerman, M. S., $\ddagger$ Asst. Dairy Husb.

G. A. Bowling, M. S., Assoc. Dairy Husb.

W. C. Brown, Ph. D., Asst. In Dalry Husb.

L. J. Manus, M. S., Asst. in Dairy Husb.

\section{ECONOMICS}

W. W. Armentrout, Ph. D. Agricultural Economist

M. A. Abrahamsen, M. A., Asst. Agr. Econ.

F. D. Cornell, Jr., Ph. D., Assoc. Agr. Econ.

L. F. Herrmann, M. S., Asst. in Agr. Econ.

W. I. Lanham, B. S, Asst, in Agr. Econ.

E. O. Leonard, B. S., Asst in Agr. Econ.

E. C. Weitzell, M. S.,* Asst. Agr. Econ.

\section{ENTOMOLOGY}

L. M. Peairs, Ph. D., Entomologist Edwin Gould, B. S., *†† Assoc. Ent.

E. O. Hamstead, A. M., Asst. in Ent.

\section{FORESTRY}

W. C. Percival, Ph. D., Assoc. Forester

L. F. Besley, M. F., Assoc. For.

H. D. Erickson, Ph. D., Asst. For.

I. E. Lutz, Research Asst.

\section{HOME ECONOMICS}

Hazel C. Cameron, M. S., Assoc. Physiologist

\section{HORTICULTURE}

R. S. Marsh, M. S., Horticulturist E. P. Brasher, M. S., Asst. in Hort.

W. H. Childs, M. S., Asst. in Hort. W. H. Duis, M. S., Asst. in Hort.

A. P. Dye, M. S., Asst. in Hort.

R. H. Sudds, Ph. D., Asst. Hort.

K. C. Westover, Ph. D., Assoc. Hort.

\section{PIANT PATHOLOGY}

J. G. Leach, Pl. D., Plant Pathologist Anthony Berg, M. S., Assoc. Plant Path.

Genevieve B. Clulo, M. A.., Asst. in Plant Path.

L. M. Hill, M. S. Asst. in Plant Path.

L. H. Leonian, Ph. D., Mycol.

V. G. Lilly, Ph. D., Asst. Physiol.

E. A. Marten, Ph. D., Asst. Bact.

C. F. Taylor, Ph. D., Asst. Plant Path.

\section{MISCELLANEOUS}

L. G. Watson, A. B., Photographer

*In cooperation with the U. S. Department of Agriculture, Washington, D. C. tIn charge of the Lakin Experiment Farm, Lakin, W. Va. In charge of the Iieymann Memorial Farms, Wardensville, W. Va, t+In charge of the University Experiment Farm, Kearneysville, W. Va. 
BULLETIN 290

DECEMBER 1938

EPISTLE TO THE FARM

by C. R. ORTON 
